\title{
Tyrosine Kinase Inhibitors for the Treatment of Rheumatoid Arthritis
}

\author{
Jose A. Gomez-Puerta ${ }^{1, *}$ and Attila Mócsai ${ }^{2}$
}

${ }^{I}$ Division of Rheumatology, Immunology and Allergy, Brigham and Women's Hospital, Boston, MA, USA; ${ }^{2}$ Department of Physiology, Semmelweis University School of Medicine, Budapest, Hungary

\begin{abstract}
Tyrosine kinases (TK) are enzymes capable of transferring phosphate groups to tyrosine residues in cytoplasmic proteins or the intracellular domains of transmembrane receptors. TK play critical roles in diverse biological functions including cellular processes such as adhesion, motility, proliferation, cell cycle control, cell death, as well as biological functions at the whole-organism level such as growth and development, metabolism or immune defense. TK inhibitors including spleen TK (fostamatinib) and Janus kinases (tofacitinib) inhibitors are two novel oral therapies that have demonstrated short-term good clinical responses in active rheumatoid arthritis patients with and inadequate responses to methotrexate or other traditional (non-biologic) disease-modifying antirheumatic drugs (DMARDs). Those responses are comparable to responses rates from pivotal trials of TNF inhibitors. TK inhibitors are generally well tolerated but not free of adverse effects. Several side effects had been described including gastrointestinal symptoms, neutropenia, hypertension, elevated liver function test and lipid alterations among others.
\end{abstract}

Owing to the limited duration of follow-up of patients treated with TK inhibitors, the long term safety profile of these drugs are unknown.

Keywords: Tyrosine kinases, fostamatinib, tofacitinib, rheumatoid arthritis, disease-modifying antirheumatic drugs.

\section{INTRODUCTION}

During the last decade the emerging of biologic therapies dramatically changed the course of several rheumatic diseases, especially rheumatoid arthritis (RA). Currently, eight biologic agents are approved as first-line or second-line therapy in RA, including five (adalimumab, certolizumab, etanercept, golimumab and infliximab) targeting tumor necrosis factor (TNF) and three (abatacept, rituximab and tocilizumab) targeting co-stimulation of T cells, B cells, and interleukin (IL) 6 , respectively. These agents already provide a broad armamentarium for rheumatologists, and have dramatically changed RA therapy during the past decade. They substantially improve synovitis and slow, or even halt, radiographically-detectable RA progression [1].

Although existing biologic agents can be switched or given in a different sequence if patients fail or adverse effects develop, there remains a need for additional therapies with different mechanisms of action for the treatment of RA. In addition, new oral DMARD tyrosine kinase (TK) inhibitors [2] that work fast with similar efficacy to the anti-TNF therapies and reasonable toxicity profiles will be value in the management of RA.

In the present review, we discuss the different physiological effects of TK over diverse biological functions and describe in detail the recent published trials in RA with 2 different non-receptor TK inhibitors including fostamatinib

*Address correspondence to this author at the Division of Rheumatology, Immunology and Allergy, PBB-B3, Section of Clinical Sciences (221 Longwood Ave, $3^{\text {rd }}$ floor), Brigham and Women's Hospital 75 Francis St. Boston, MA 02115, USA; E-mail: JGOMEZPUERTA@partners.org and tofacitinib. Additionally, we mention briefly other developing therapies in the field. The chemical structure of 3 different TK used in RA is presented in Fig. 1.

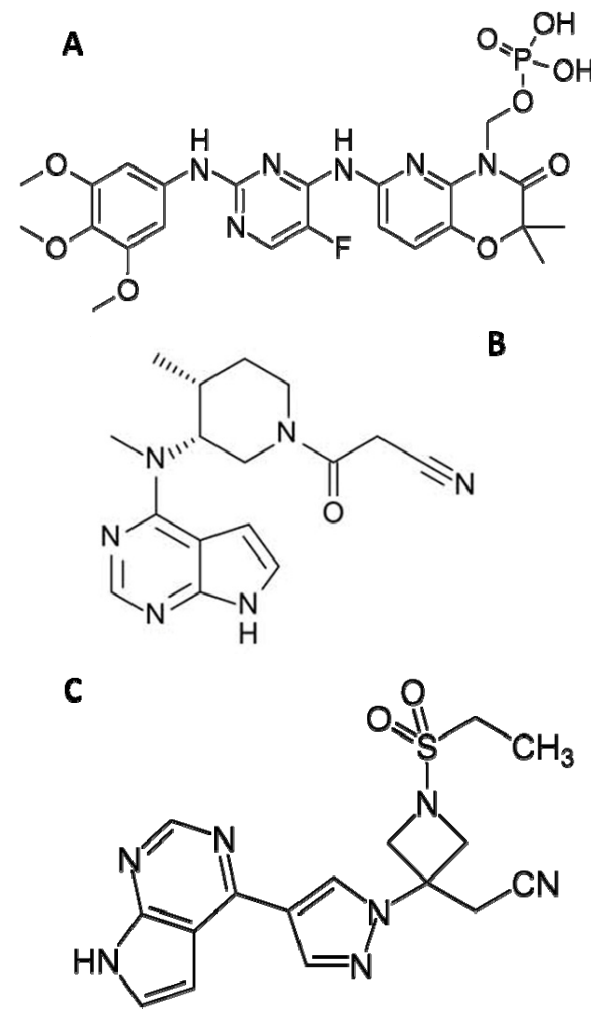

Fig. (1). Chemical structure of 3 different TK inhibitors used in RA (A. Fostamatinib, B. Tofacitinib, C. Baricitinib). Modified from http://commons.wikimedia.org/wiki/Main_Page 


\section{TYROSINE KINASES}

TK are enzymes capable of transferring phosphate groups to tyrosine residues in cytoplasmic proteins or the intracellular domains of transmembrane receptors. Tyrosine phosphorylation of target molecules results in changes in intracellular signal transduction processes, either by affecting the enzymatic activity of the target proteins (enzymes) and/or by allowing the association of the target proteins (such as adapter molecules) with other molecules inside the cell. TK play critical roles in diverse biological functions including cellular processes such as adhesion, motility, proliferation, cell cycle control or cell death, as well as biological functions at the whole-organism level such as growth and development, metabolism or immune defense. Based on their major role in proliferation, migration and cell survival, several TK are involved in cancer development. Indeed, the first identified oncogene ( $\mathrm{v}-\mathrm{Src}$, the viral homolog of the Src TK) and the best known chromosomal aberration leading to malignancy (the emergence of the BCR-Abl fusion protein as a result of the Philadelphia translocation, leading to chronic myelogenous leukemia) are all linked to aberrant TK signaling pathways.

TK can be grouped into receptor TK (such as the insulin receptor or EGF-receptors) which are transmembrane receptors carrying a TK domain in their intracellular segment; or intracellular (non-receptor) TK (such as Src-family kinases, Syk or JAK kinases) which reside entirely in the cytoplasm. There are approximately $90 \mathrm{TK}$ in the mammalian genome, with approximately 60 receptor TK and approximately 30 non-receptor TK [3].

Receptor TK consist of extracellular domains involved in ligand binding, a transmembrane domain, as well as intracellular domains with TK enzymatic activity. A common feature of receptor TK is the autophosphorylation of intracellular tyrosine residues within the receptor itself, leading to further amplification of the kinase activity and the emergence of tyrosine-phosphorylated docking sites for additional signal transduction molecules [4]. The docking of other signaling molecules and the phosphorylation of further downstream targets triggers downstream phosphorylation events. Typical receptor TK include the EGF-receptor family and the insulin receptor, but receptors for other growth factors (such as various FGF, VEGF, IGF or PDGF molecules), as well as Eph receptors also belong to this family.

Non-receptor TK reside in the cytoplasm but become associated to and/or activated by receptors that lack any direct enzymatic activity (such as integrins, immunoreceptors or cytokine receptors). Besides their kinase domain, nonreceptor TK usually contain various additional signal transduction domains such as $\mathrm{SH} 2-$ or SH3-domains responsible for regulated binding to other signaling molecules. Typical non-receptor TK include the Src-family and Tec-family kinases, as well as the Syk/ZAP-70, JAK, FAK/Pyk2 or Abl/Arg TK [3].

As proteins with enzymatic activity, TK are relatively easy to target using small molecule inhibitors. Such TK inhibitors usually inhibit the kinase by competing for ATP in the ATP-binding pocket. Because of the conserved nature of the ATP-binding pockets, many TK inhibitors are of limited specificity towards their target molecule and rather inhibit a broader range of TK. However, newer compounds with more sophisticated structural features may attain higher specificity towards a given TK or TK family. There is debate about the clinical benefit of high specificity. While specificity towards one unique kinase may be beneficial in cases where disease pathogenesis relies on a single molecular entity, a more widespread dampening of various TK pathways may provide additional benefit in cases where a number of tyrosine phosphorylation pathways contribute to disease pathogenesis.

As mentioned above, TK are best known in medicine for their role in the development and progression of cancer and other malignant states, and therefore are prominent targets for anti-cancer therapeutics. One of the best known cases of rational drug design (when a drug is specifically developed to inhibit a given target molecule known to be involved in a given disease pathogenesis) is the development of imatinib, an Abl TK inhibitor, for the treatment of chronic myelogenous leukemia (CML) [5,6]. A number of additional inhibitors such as gefitinib and erlotinib targeting the EGFreceptor TK, sunitinib targeting other growth factor receptors, as well as various second-generation TK inhibitors such as nilotinib, dasatinib or bosutinib have also been developed for the treatment of various cancers and other malignant states [7].

Basic biomedical studies during the last decades have indicated that TK are not only involved in processes critical for cancer development, such as cellular proliferation and survival, but they are also indispensable for various more specific biological processes such as development and function of immune cells, bone metabolism, platelet function or pathological functioning of non-hematopoietic cell types [818]. Accordingly, TK have begun to emerge as important therapeutic targets in non-malignant diseases including autoimmune and inflammatory diseases.

Of the numerous kinases implicated in immune defense and inflammation, we will pay special attention to two nonreceptor TKs, the Syk TK and the JAK kinase family. These molecules have received special attention as targets of TK inhibitors under development for the therapy of autoimmune diseases such as RA.

\section{THE SYK TYROSINE KINASE}

Spleen TK (Syk) is a cytoplasmic TK highly expressed in most hematopoietic lineages except T-cells where ZAP-70 is the dominant Syk-related kinase [19]. The primary function of Syk (and ZAP-70 in T-cells) is to transmit signals from classical immunoreceptors such as B- and T-cell-receptors on lymphocytes, as well as Fc $\gamma$ - and Fce-receptors on myeloid cells and mast cells (Fig. 2A). Because of the critical role for Syk in the BCR-dependent B-cell activation and immunoglobulin secretion, as well as the Fc-receptormediated effector functions of antibodies, genetic or pharmacological reduction of Syk activity strongly impairs antibody-mediated functional responses [8,20-22]. Importantly, Syk in B-cells is not only involved in immunoglobulin production but it is also required for B-cell survival due to the requirement for a Syk-dependent tonic BCR signaling. Therefore, deletion or inhibition of Syk not only interferes with antibody production but also inhibits antibody- 
independent functions of B-cells, such as B-cell-mediated antigen presentation to T-cells $[8,23]$. Syk is also involved in signaling by various adhesion receptors, including integrins and selectins, on myeloid cells $[8,24,25]$, therefore affecting myeloid cell function independent of their role in adaptive immunity. Syk is also a critical player of the signal transduction of various C-type lectins (including Dectin-1, Dectin-2 and Mincle) which are involved in innate pathogen recognition by myeloid cells but also in sensing tissue damage through innate receptors for damage-associated molecular patterns[8,26] (Fig. 2A). Importantly, Syk is also required for osteoclast development and osteoclast-mediated bone resorption [27], indicating that it may also be involved in bone erosions during joint inflammation. Furthermore, Syk has also been implicated in signal transduction in synovial cells of non-hematopoietic origin [28,29], as well as in endothelial cell function $[30,31]$. Taken together, Syk plays critical roles in both the adaptive and innate mechanisms of immunity and inflammation, and it is also required for the development and function of osteoclasts and signal transduction in synovial cells. This diverse function in inflammationrelated signaling processes makes it an exceptional candidate for the development of signal transduction inhibitor therapies in autoimmune and inflammatory diseases. Indeed, targeting Syk could potentially benefit patients with RA or other autoimmune diseases by multiple ways including 1) decreasing the inflammatory response by inhibiting lymphoid and myeloid leukocytes; 2) preventing the development or progression of bone erosion via inhibition of osteoclast function; and 3) by affecting various cells of non-hematopoietic origin (synovial fibroblasts, endothelial cells) that are involved in development of arthritis and other autoimmune diseases.

The role of Syk in various inflammatory cells has prompted investigators to test its role in preclinical in vivo animal models of RA or systemic lupus erythematosus (SLE). Pharmacological inhibition of Syk by the Syk inhibitor fostamatininb (R788) or its active metabolite (R406) reduced the severity of autoantibody-induced arthritis in experimental mice [32] as well as in collagen-induced arthritis in experimental rats [33]. It should be noted that R406/fostamatinib is known to inhibit a number of kinases and non-kinase targets other than Syk [32,34,35], raising the possibility that the effect of the inhibitors were caused by targeting molecules other than Syk. Importantly, however, autoantibody-induced arthritis in experimental mice was also completely blocked by the genetic deficiency of Syk in the hematopoietic compartment [36], providing direct evidence for the role of Syk in arthritis development. An interesting observation from the clinical perspective was that both fostamatinib [33] and the genetic deficiency of Syk [36] prevented the development of arthritis-induced bone erosions. Besides the various arthritis models, the Syk inhibitor fostamatinib has also been shown to inhibit kidney and skin disease in murine models of SLE [37,38].

\section{JAK-FAMILY TYROSINE KINASES}

The Janus kinase (JAK) family comprises four nonreceptor tyrosine kinases designated Jak1, Jak2, Jak3 and Tyk2. JAKs were identified as novel kinases of unknown function and were originally designated "Just Another Kinase", obviously not expecting that this family will soon be recognized as a major player in diverse biological functions and an important target of various autoimmune and other diseases.

JAK kinases consist of various intracellular domains including a tyrosine kinase domain, a catalytically inactive (but functionally important) pseudokinase domain, as well as an SH2- and a FERM domain which are involved in proteinprotein interactions [9]. Jak1, Jak2 and Tyk2 are ubiquitously expressed whereas Jak3 is primarily expressed in hematopoietic lineages [39].

JAK kinases are intimately involved in signal transduction by various cytokine receptors. Based on structural features of the receptors and their ligands, cytokine receptors are grouped into two families [40] (Fig. 2B). Type I cytokine receptors are characterized by a membrane-proximal extracellular WSXWS motif and recognize ligands with $4 \alpha$ helical structures. Those receptors include, among others, receptors for IL-2, IL-3, IL-4, IL-6, IL-12, erythropoietin (Epo), G-CSF and GM-CSF [40]. Type II cytokine receptors do not contain WSXWS motifs and recognize ligands with 6 $\alpha$-helical structures [41]. Type II cytokine receptors primarily recognize IFN $\alpha / \beta$ (Type I IFNs), IFN $\gamma$ (Type II IFN) and IL-10.

Both Type I and Type II cytokine receptors are dimeric or multimeric transmembrane receptors lacking any enzymatic activity but carrying a number of potential tyrosine phosphorylation sites. JAK kinases are constitutively associated with the receptors making some investigators propose that cytokine receptor - JAK interactions are reminiscent of receptor tyrosine kinases [42] (Fig. 2B). Receptor ligation leads to conformational changes triggering activation of the JAK kinase activity. Activation of JAK kinases leads to three levels of tyrosine phosphorylation events (Fig. 2B): 1) JAKs catalyze autophosphorylation, triggering further increase of their kinase activity; 2) they also lead to phosphorylation of tyrosine residues on the cytokine receptor which recruits further molecules, including various STAT transcription factors to the receptor; and 3) receptor-bound STAT proteins are also phosphorylated by JAKs. Tyrosine phosphorylated STAT molecules are then released from the receptor, dimerize, shuttle to the nucleus and bind to various STAT target genes, triggering specific changes of gene expression.

JAK family kinases (through the activation of STAT transcription factors) are involved in a variety of effects of cytokines. Those include the activation of T-cell proliferation by IL-2; the polarization of Th cells to the Th1 or Th2 lineages through IFN $\gamma$, IL-4 and other cytokines; activation of innate immune responses through IFN $\alpha$; differentiation of immune cells by G-CSF and GM-CSF; as well as various non-immunological functions such as effects of Epo, growth hormone or prolactin. This pleiotropic effect of JAK kinases may explain that genetic deletion of Jak1 or Jak2 causes embryonic or perinatal lethality $[43,44]$. On the other hand, genetic deficiency of Jak3 does not lead to lethality but causes severe combined immunodeficiency (SCID) in humans $[45,46]$ and a corresponding phenotype with severe lymphocyte developmental defects in mice $[47,48]$. Tyk2 deficiency in mice causes partial defects in cytokine signal transduction, especially in the case of IFN $\alpha$ and IL-12 signal transduction, leading to diminished antiviral immune responses [49,50]. Interestingly, signal transduction by $\mathrm{IL}-4$ is increased in 
A

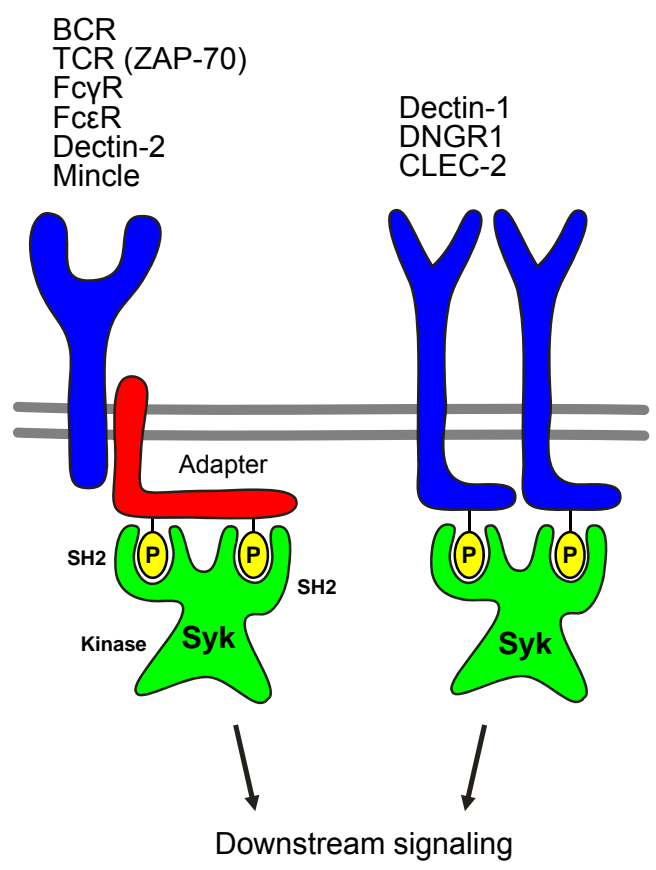

B Type I receptors:

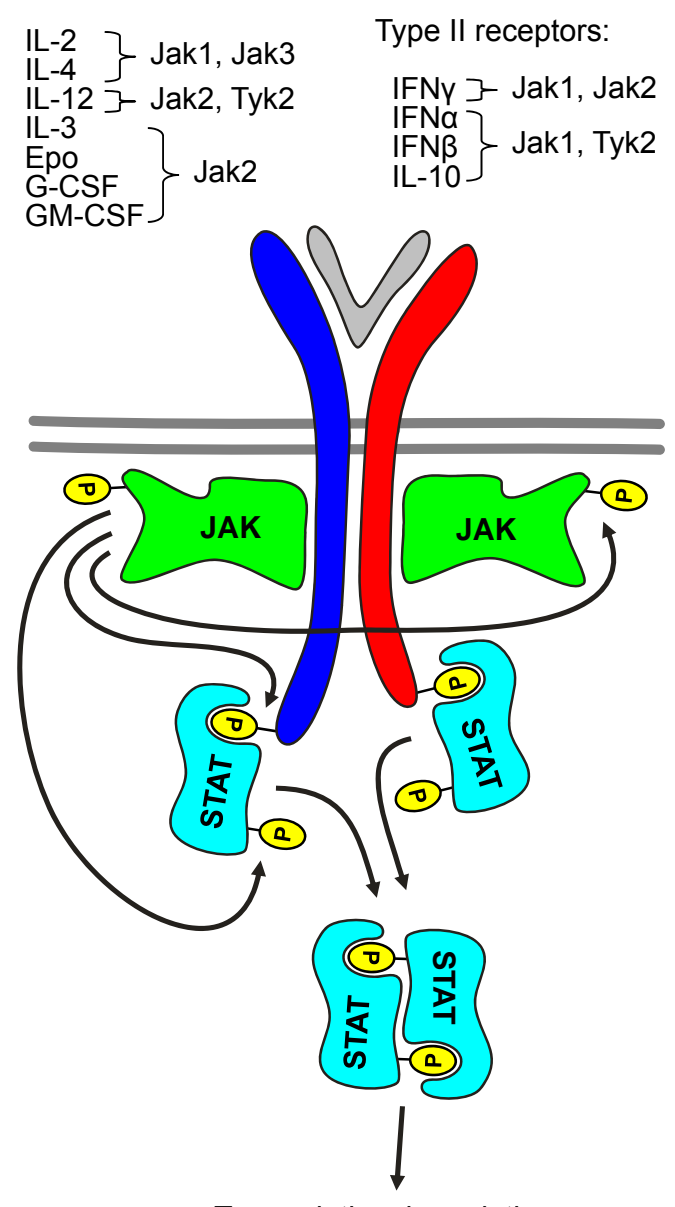

Transcriptional regulation
Fig. (2). Stucture and signaling pathways of Syk and JAK.

Tyk2-deficient animals, leading to increased IgE production and exaggerated allergic responses [39]. Corresponding immunological changes were found in a human patient with Tyk2 deficiency, who suffered from recurring viral, fungal and mycobacterial infections with atopic dermatitis and elevated serum $\operatorname{IgE}$ (originally diagnosed as a hyper $\operatorname{IgE}$ syndrome) [51]. Taken together, Tyk2 appears to be responsible for directing Th-cell polarization towards pro-inflammatory (Th1) rather than pro-allergic (Th2) responses in both mice and humans. Besides the above findings on JAK deficiency, a unique gain-of-function mutation of Jak2 (Val617Phe) is found in most patients with myeloproliferative disorders such as polycythemia vera [52-56].

A major conceptual difficulty in understanding the role of JAK family kinases in immunity and inflammation is that these kinases are intimately involved in signal transduction by a very large number of cytokine receptors, therefore there is little room for specificity of the different JAK kinases towards specific cytokine receptors. Further complicating this issue is that certain cytokine receptors also use two different JAKs which can either play non-redundant or overlapping functions (i. e. deletion of one or both is required for abrogating of signal transduction) (Fig. 2B). As an example, IL-2 and IL-4 signaling uses Jak1 and Jak3, both of which are required for signal transduction, and both Jak1 and Jak2 are required for IFN $\gamma$ signaling [40]. In contrast, IL-12 uses Jak2 and Tyk2, but only Tyk2 (but not Jak2) is indispensable for signal propagation [40]. Yet other cytokines such as IL-3, GM-CSF or Epo use exclusively Jak2 which is required for their signaling [40].

Taken together, JAK kinases are intimately involved in signal transduction by various cytokine receptors and, given the role of cytokines in various phases of autoimmune arthritis [57], their inhibition is expected to provide clinical benefit by dampening the overall inflammatory process. In addition, specific inhibitors of each JAK family kinases are expected to result in unique patterns of inhibition of a limited set of inflammatory processes. Jak inhibitors, such as tofacitinib, are expected to provide an overall inhibition of proinflammatory signaling pathways by inhibiting IL-2 and IL-4 signaling, with limited effect on homeostatic processes (mediated e. g. by IL-3, Epo or G/GM-CSF). In contrast, Jak2 inhibitors primarily affect homeostatic cytokine signaling pathways (e. g. that of IL-3, Epo and G/GM-CSF) and therefore primarily provide benefit in myeloproliferative diseases, especially in those with a gain-of-function Jak2 mutation [58]. 
Based on the above observations, a number of JAK inhibitors have been developed and tested in various inflammation models in experimental mice. The most widely studied of those inhibitors is tofacitinib (CP-690550) which primarily inhibits Jak1 and 3 primarily but also exerts some inhibitory effects on Jak2 [59]. Tofacitinib prevented clinical signs of inflammation and cartilage degradation in active models of arthritis in rodents $[60,61]$ and it also prevented cartilage damage upon transplantation of human RA synovial cells and cartilage tissue to SCID mice [62]. Tofacitinib also inhibited delayed-type hypersensitivity reactions [63], and it prevented allograft rejection in various animal models of transplantation, indicating that it may be suitable as a novel immunosuppressive therapy in transplant recipients $[63,64]$.

\section{FOSTAMATINIB TRIALS}

To date, three phase II clinical trial of fostamatinib have been published [65], [66], [67]. The design of those trials is collected in Table $\mathbf{1}$.

In the first trial (TASKi1), Weinblatt et al [65] evaluated three different doses of fostamatinib $(50,100$ and $150 \mathrm{mg}$ b.i.d) vs placebo over 12 weeks in 189 patients with active RA defined as $>6$ swollen joints, $>6$ tender joints (28-joint count) and either an erythrocyte sedimentation rate (ESR) $>28 \mathrm{~mm} /$ hour, a C-reactive protein (CRP) level > upper limit of normal, or morning stiffness of $>45$ minutes' duration. The primary endpoint (ACR20 response at week 12) was met in $65 \%$ and $72 \%$ of patients in $100 \mathrm{mg}$ and $150 \mathrm{mg}$ groups, respectively vs $38 \%$ in placebo group ( $\mathrm{p}<0.05$ for both). Additionally, ACR50 and ACR70 responses and disease activity score (DAS) in 28 joints (DAS-28) CRP $(<2.6)$ rates were significant higher in $100 \mathrm{mg}$ and $150 \mathrm{mg}$ groups vs placebo. There was a significant decrease from baseline in serum IL-6 and MMP-3 levels in the 2 higher dose groups (100 $\mathrm{mg}$ and $150 \mathrm{mg}$ ) vs placebo at week 12 ( $p=0.05$ for IL6 level in the $100 \mathrm{mg}$ group, $p<0.001$ for IL-6 level in the $150 \mathrm{mg}$ group, and $\mathrm{P}<0.01$ for MMP-3 level in both highdose groups).

In the second trial (TASKi2), Weinblatt and colleagues [66] analyzed the efficacy of fostamatinib in a multicenter, randomized, double-blind trial including 457 patients with active RA [mean DAS28 6.1] despite long-term DMARD therapy [methotrexate (MTX) and/or biologic agents] and mean disease duration of 9 years. After 6 months of treatment, the authors reported significantly higher ACR20 response rates in patients receiving fostamatinib at doses of $100 \mathrm{mg}$ b.i.d or $150 \mathrm{mg}$ once daily (67\% and $57 \%$, respectively, versus $35 \%$ with placebo; $\mathrm{P}<0.001$ for both comparisons). ACR50 and ACR70 response rates at 6 months were substantially higher than placebo in both treatment groups, and similar to those achieved in clinical trials of other biologic agents in patients with inadequate responses to DMARDs.

Although response rates were reduced in the $15 \%$ of patients who had not responded adequately to treatment with biologic agents, ACR20 responses in this subgroup were still significant $(43 \%$ and $46 \%$ respectively, versus $14 \%$ with placebo; $\mathrm{p}=0.04$ and $\mathrm{p}=0.02$, respectively).
Low disease states (indicated by a DAS28 score <2.6) 6 months after treatment with fostamatinib were high $(21 \%$ and $31 \%$ in the $150 \mathrm{mg}$ once daily and $100 \mathrm{mg}$ twice daily groups, respectively, versus $7 \%$ with placebo; $p=0.003$ and $\mathrm{p}<0.001$ respectively).

Patients receiving $100 \mathrm{mg}$ of fostamatinib twice daily also showed improvement in the Functional Assessment of Chronic Illness Therapy fatigue scale and the four dimensions of the Medical Outcomes Study 36-Item Short Form Health Survey.

In the third trial (TASKi3), Genovese et al [67] evaluated the efficacy of fostamatinib (R788) in 219 active RA patients who had failed biologic treatment (anti-TNF and non-antiTNF therapies). Patients were randomly assigned to oral fostamatinib $(n=143)(100 \mathrm{mg}$ bid $)$ or placebo $(n=73)$. Efficacy and safety were evaluated for 3 months by clinical parameters and hand and wrist MRI.

The primary endpoint was the ACR20 response. Secondary endpoints included ACR50, ACR70 responses and changes in radiological/structural damage at month 3 using the OMERACT-RAMRIS method.

No significant differences were found in ACR 20/50/70 responses at 3 months. However, the mean change in DAS28 score was greater in fostamatinib patients (1.62 vs -1.27 in placebo group, $\mathrm{p}=0.15)$. $\mathrm{CRP}$ and ESR changes at month 3 were higher in fostamatinib patients $(-6.87 \pm 29 \mathrm{vs}+3.62 \pm$ $18 \mathrm{mg} / \mathrm{L}$ and $-8.9 \pm 21$ vs $+1.41 \pm 25 \mathrm{~mm} / \mathrm{hr}$, respectively), and mean synovitis scores $(-0.5$ versus +0.4 for placebo, $\mathrm{p}=$ $0.038)$ and mean osteitis scores $(-0.2$ versus $+1.2, \mathrm{p}=0.058)$ were significantly lower in fostamatinib patients. Patients with higher baseline CRP levels and MRI activity (synovitis) had a higher ACR20 response to fostamatinib in comparison with placebo ( $42 \%$ vs $26 \%$; $=0.05$ ). In a post hoc analysis it was determined that there was an extremely high placebo response $(>60 \%)$ in the patients who enrolled in the study with an elevated ESR but a normal CRP. A Phase III study is in progress looking at this drug in a TNF failure population.

\section{JANUS KINASE INHIBITORS}

\section{Tofacitinib}

A very extensive Phase II and III program has completed with tofacitinib and US Food and Drug Administration on November 6 of 2012 announced the approval of tofacitinib as a second-line treatment for moderate to- severe RA in adults [68].

Study design from phase II and phase III studies is summarized in Table 2. The first randomized, double-blind, placebo-controlled, phase IIa trial [69] evaluated the efficacy of three different doses of tofacitinib $(5,15$ or $30 \mathrm{mg}$ bid) vs placebo over a 6 weeks in 264 patients with an active RA despite previous MTX or biologic treatment. ACR20 response was achieved in 70, 81 and $77 \%$ of patients treated with 5,15 and $30 \mathrm{mg}$ of tofacitinib, respectively vs $29 \%$ of patients treated with placebo. DAS28, ACR50 and ACR70 responses were also significantly higher in the three active treatment groups. Adverse events were dose-related dependent; being more common in those patients who received 15 and $30 \mathrm{mg}$. Additional Phase II and III programs lowered the 
Table 1. Design of Three Phase II RCT in RA Patients Treated with Fostamatinib

\begin{tabular}{|c|c|c|c|c|c|c|c|c|}
\hline First Author & Drug & $\begin{array}{c}\text { No. Patients/ } \\
\text { Treatment } \\
\text { arms }\end{array}$ & $\begin{array}{l}\text { Inclusion } \\
\text { criteria }\end{array}$ & $\begin{array}{c}\text { Type of RA } \\
\text { patients }\end{array}$ & Follow-up & $\begin{array}{l}\text { Primary } \\
\text { endpoint }\end{array}$ & $\begin{array}{l}\text { Secondary } \\
\text { endpoints }\end{array}$ & Ref. \\
\hline $\begin{array}{c}\text { Weinblatt et al } \\
\text { TASKi2 }\end{array}$ & FOSTA & $\begin{array}{c}\text { Total }=457 / \\
\text { PBO }(\mathrm{n}=153), \\
\text { FOSTA } 150 \\
\text { mg o.d } \\
(\mathrm{n}=152) \\
\text { FOSTA 100 } \\
\text { mg b.i.d } \\
(\mathrm{n}=152)\end{array}$ & $\begin{array}{c}\geq 6 \mathrm{STC}, \\
\geq 6 \mathrm{TJC} \text { and } \\
\mathrm{ESR}>28 \mathrm{~mm} \\
\text { or } \mathrm{CRP}>7 \\
\mathrm{mg} / \mathrm{L}\end{array}$ & $\begin{array}{l}\text { Active RA } \\
\text { with an inade- } \\
\text { quate response } \\
\text { to DMARD } \\
\text { (biologic and } \\
\text { non-biologic) }\end{array}$ & $6 \mathrm{mo}$ & $\begin{array}{l}\text { ACR20 } \\
\text { response at } \\
\text { mo } 6\end{array}$ & $\begin{array}{c}\text { - ACR50, } \\
\text { ACR70 res- } \\
\text { ponses } \\
\text { - DAS28 } \\
\text { - Remission } \\
\text { (DAS28 < 2.6) } \\
\text { - FACIT }\end{array}$ & [66] \\
\hline $\begin{array}{c}\text { Genovese et al } \\
\text { TASKi3 }\end{array}$ & FOSTA & $\begin{array}{c}\text { Total }=219 / \\
\text { PBO }(\mathrm{n}=73) \\
\text { FOSTA 100 } \\
\text { mg b.i.d } \\
(\mathrm{n}=146)\end{array}$ & $\begin{array}{c}\geq 6 \mathrm{STC}, \\
\geq 6 \text { TJC and } \\
\text { ESR }>28 \mathrm{~mm} \\
\text { or } \mathrm{CRP}>8 \\
\mathrm{mg} / \mathrm{L}\end{array}$ & $\begin{array}{c}\text { Active RA } \\
\text { with an inade- } \\
\text { quate response } \\
\text { to biologic } \\
\text { treatment }\end{array}$ & $3 \mathrm{mo}$ & $\begin{array}{l}\mathrm{ACR} 20 \\
\text { response at } \\
\text { mo } 3\end{array}$ & $\begin{array}{l}\text {-ACR50 and } \\
\text { ACR70 } \\
\text { responses, - } \\
\text { Improvements } \\
\text { in individual } \\
\text { ACR compo- } \\
\text { nents and } \\
\text { DAS28 } \\
\text { - Changes } \\
\text { from baseline } \\
\text { to mo } 3 \text { in } \\
\text { radi- } \\
\text { ologic/structur } \\
\text { al responses } \\
\text { by OMER- } \\
\text { ACT and } \\
\text { RAMRIS }\end{array}$ & [67] \\
\hline
\end{tabular}

b.id: twice daily, CRP: C Reactive protein, DAS28: Disease Activity Score-28 joints, ESR: erythrocyte sedimentation rate, FACIT : Functional Assessment of Chronic Illness Therapy, FOSTA: Fostamatinib, HAQ-DI: Health assessment questionnaire-Disability Index, Mo: Months, MTX: Methotrexate, o.d: once daily OMERACT: Outcome Measures in Rheumatology Clinical Trials, PBO: Placebo, RAMRIS: Rheumatoid arthritis MRI Scoring method, SJC: Swelling joint count, TJC: Tender joint count

doses to 5 and $10 \mathrm{mg}$ bid based on the higher rate of adverse events seen with the 15 and $30 \mathrm{mg}$ dosing groups.

There have 4 Phase III studies completed of which 2 have been published and will be reviewed. Recently, Fleischmann and colleagues [70] performed a double-blind, parallel group study testing tofacitinib. The study evaluate the efficacy and safety of monotherapy tofacitinib over 6 months in 611 patients with active RA. Patients were randomly assigned to tofacitinib 5 or $10 \mathrm{mgs}$ b.i.d or placebo. At 3 months non responders in the placebo group were assigned in a blinded manner to receive tofacitinib 5 or $10 \mathrm{mg}$ of tofacitinib b.i.d for an additional 3 months. Both doses of tofacitinib proved superior to placebo on improvement in ACR responses and scores in the health assessment questionnaire-disability index (HAQ-DI). Patients in the 5-mg group experienced a 0.5 -point drop in HAQ-DI scores; those in the 10-mg group a 0.57 -point decline compared with those in the placebo group, in which scores dropped 0.19 points ( $\mathrm{p}$ $<0.001)$. Patients who were switched from placebo to tofacitinib at month 3 had similar ACR responses and HAQ-DI scores by month 6 to those patients assigned to tofacitinib from the beginning of the study.

van Vollenhoven and colleagues [71] evaluated on a background of stable MTX two different doses of tofacitinib ( 5 and $10 \mathrm{mg}$ b.id) or adalimumab (40 mg every 2 weeks) vs placebo over 24 weeks in 717 patients with active RA. After 3 months those patients assigned to placebo who did not reach a $20 \%$ reduction in number of TJC and SJC were randomly assigned to receive either $5 \mathrm{mg}$ or $10 \mathrm{mg}$ of tofacitinib. The study included patients with active RA (see Table 2 for definition) with a mean disease duration ranged from 7-9 years and an incomplete response to MTX. 
Table 2. Design of Phase II and Phase III RCT in RA Patients Treated with Tofacitinib

\begin{tabular}{|c|c|c|c|c|c|c|c|c|}
\hline First Author & Drug & $\begin{array}{c}\text { No. Patients/ } \\
\text { Treatment } \\
\text { arms }\end{array}$ & $\begin{array}{c}\text { Inclusion Crite- } \\
\text { ria }\end{array}$ & $\begin{array}{l}\text { Type of RA } \\
\text { Patients }\end{array}$ & Follow-up & $\begin{array}{l}\text { Primary } \\
\text { Endpoint }\end{array}$ & $\begin{array}{l}\text { Secondary } \\
\text { endpoints }\end{array}$ & Ref. \\
\hline Kremer et al. & TOFA & $\begin{array}{c}\text { Total }=264 / \\
\text { PBO }(\mathrm{n}=65) \\
\text { TOFA } 5 \mathrm{mg} \\
(\mathrm{n}=61), \text { TOFA } \\
15 \mathrm{mg}(\mathrm{n}=69), \\
\text { TOFA } 30 \mathrm{mg} \\
(\mathrm{n}=69)\end{array}$ & $\begin{array}{c}\geq 6 \mathrm{STC}, \\
\geq 9 \mathrm{TJC} \text { of } 66- \\
\text { joint count and } \\
\text { ESR }>28 \mathrm{~mm} \text { or } \\
\mathrm{CRP}>10 \mathrm{mg} / \mathrm{L}\end{array}$ & $\begin{array}{l}\text { Active RA with } \\
\text { an inadequate } \\
\text { response to } \\
\text { MTX, ETC, INF } \\
\text { or ADA }\end{array}$ & $3 \mathrm{mo}$ & $\begin{array}{l}\text { Efficacy of TOFA } \\
\text { (in dosages of } 5,15 \text {, } \\
30 \mathrm{mg} \text { b.i.d) with } \\
\text { PBO over } 6 \text { weeks }\end{array}$ & $\begin{array}{l}\text { Safety and } \\
\text { tolerability }\end{array}$ & [69] \\
\hline Tanaka et al. & MTX + TOFA & $\begin{array}{c}\text { Total }=140 / \\
\text { PBO }(\mathrm{n}=28) \\
\text { TOFA } 1 \mathrm{mg} \\
(\mathrm{n}=28), \text { TOFA } 3 \\
\mathrm{mg}(\mathrm{n}=27), 5 \mathrm{mg} \\
(\mathrm{n}=27), 10 \mathrm{mg} \\
(\mathrm{n}=26) \text { all b.i.d }\end{array}$ & $\begin{array}{c}\geq 6 \mathrm{STC}, \\
\geq 6 \mathrm{TJC} \text { of } 66- \\
\text { joint count and } \\
\text { ESR }>28 \mathrm{~mm} \text { or } \\
\mathrm{CRP}>0.7 \mathrm{mg} / \mathrm{dl}\end{array}$ & $\begin{array}{l}\text { Active RA with } \\
\text { an inadequate } \\
\text { response to } \\
\text { MTX }\end{array}$ & $3 \mathrm{mo}$ & $\begin{array}{c}\text {-ACR20 response at } \\
\text { mo } 3 \\
\text { - HAQ-DI } \\
\text { - CRP at } 3 \text { mo }\end{array}$ & $\begin{array}{c}\text { ACR20, ACR50, } \\
\text { and ACR70 at } \\
\text { weeks } 1,2,4,8, \\
\text { and 12: } \\
\text { Safety and } \\
\text { tolerability }\end{array}$ & [76] \\
\hline $\begin{array}{l}\text { Fleischmann et } \\
\qquad a l .\end{array}$ & $\begin{array}{c}\text { Monotherapy- } \\
\text { TOFA }\end{array}$ & $\begin{array}{c}\text { Total= 611/ } \\
\text { PBO }(\mathrm{n}=122) \\
\text { TOFA } 5 \mathrm{mg} \\
(\mathrm{n}=243) \text { and } \\
\text { TOFA } 10 \mathrm{mg} \\
(\mathrm{n}=245)\end{array}$ & $\begin{array}{c}\geq 6 \mathrm{STC}, \\
\geq 6 \mathrm{TJC} \text { and } \\
\mathrm{ESR}>28 \mathrm{~mm} \text { or } \\
\mathrm{CRP}>7 \mathrm{mg} / \mathrm{L}\end{array}$ & $\begin{array}{l}\text { Active RA with } \\
\text { an inadequate } \\
\text { response to } \\
\text { DMARD (bio- } \\
\text { logic and non- } \\
\text { biologic) }\end{array}$ & $6 \mathrm{mo}$ & $\begin{array}{c}\text { - ACR20 at mo } 3 \\
\text { - Change in baseline } \\
\text { HAQ-DI } \\
\text { - \% patients with } \\
\text { DAS28-4[ESR] < } \\
2.6\end{array}$ & $\begin{array}{c}\text { - ACR20, } \\
\text { ACR50, ACR70 } \\
\text { responses at all } \\
\text { visits } \\
\text { - DAS28- } \\
\text { 4(ESR) and } \\
\text { DAS28-3(CRP) } \\
\text { of }<2.6 \text { or less } \\
\text { and }<3.2 \text { or less } \\
\text { at all visits up to } \\
\text { mo } 6\end{array}$ & {$[70]$} \\
\hline $\begin{array}{l}\text { van Vollenhoven } \\
\text { et al. }\end{array}$ & $\begin{array}{c}\text { MTX + TOFA } \\
\text { or ADA }\end{array}$ & $\begin{array}{c}\text { Total=717/ } \\
\text { TOFA } 5 \mathrm{mg} \\
\text { b.i.d }(\mathrm{n}=204), \\
\text { TOFA } 10 \mathrm{mg} \\
\text { b.i.d }(\mathrm{n}=201), \\
\text { ADA } 40 \mathrm{mg} \\
\text { every } 2 \text { weeks } \\
\text { (n=204), } \\
\text { PBO for } 3-6 \text { mo } \\
\text { followed by } \\
\text { TOFA } 5 \text { mg } \\
\text { (n=56) b.i.d or } \\
\text { PBO for } 3-6 \text { mo } \\
\text { followed by } 10 \\
\text { mg TOFA b.id. } \\
\quad(n=52)\end{array}$ & $\begin{array}{c}\geq 6 \mathrm{STC}, \\
\geq 6 \mathrm{TJC} \text { and } \\
\mathrm{ESR}>28 \mathrm{~mm} \text { or } \\
\mathrm{CRP}>7 \mathrm{mg} / \mathrm{L}\end{array}$ & $\begin{array}{l}\text { Active RA naïve } \\
\text { to anti-TNF with } \\
\text { MTX incom- } \\
\text { plete response }\end{array}$ & $12 \mathrm{mo}$ & $\begin{array}{c}\text { - ACR20 at mo } 6 \\
\text { - Mean change from } \\
\text { baseline to mo } 3 \text { in } \\
\text { HAQ-DI } \\
\text { - \% patients with } \\
\text { DAS28-4 [ESR] < } \\
2.6 \\
\text { - Safety of TOFA } \\
\text { during } 12 \text { mo }\end{array}$ & $\begin{array}{c}\text { - ACR20, } \\
\text { ACR50 and } \\
\text { ACR70 TOFA } \\
\text { vs PBO over } \\
\text { time } \\
\text { - Change from } \\
\text { baseline in } \\
\text { HAQ-DI and } \\
\text { DAS28-4 [ESR] }\end{array}$ & [71] \\
\hline $\begin{array}{l}\text { Burmester, GR } \\
\text { et al. }\end{array}$ & MTX + TOFA & $\begin{array}{c}\text { Total }=399 / \text { PBO } \\
\text { and then TOFA } \\
5 \mathrm{mg}(\mathrm{n}=66) \\
\text { b.i.d , PBO and } \\
\text { then TOFA } 10 \\
\text { mg }(\mathrm{n}=66) \text { b.i.d, } \\
\text { TOFA } 5 \mathrm{mg} \\
\text { b.i.d }(\mathrm{n}=133), \\
\text { TOFA } 10 \mathrm{mg} \\
\text { b.i.d }(\mathrm{n}=134)\end{array}$ & $\begin{array}{c}\geq 6 \mathrm{STC}, \\
\geq 6 \mathrm{TJC} \text { and } \\
\mathrm{ESR}>28 \mathrm{~mm} \text { or } \\
\mathrm{CRP}>7 \mathrm{mg} / \mathrm{L}\end{array}$ & $\begin{array}{l}\text { Active RA with } \\
\text { an inadequate } \\
\text { response or } \\
\text { intolerance to } \\
\text { one or more } \\
\text { TNF }\end{array}$ & $6 \mathrm{mo}$ & $\begin{array}{c}\text {-ACR20 at mo } 3 \\
\text {-Mean change from } \\
\text { baseline to mo } 3 \text { in } \\
\text { HAQ-DI } \\
\text {-Remission (DAS28- } \\
\text { 4(ESR) }<2.6)\end{array}$ & $\begin{array}{c}\text { ACR20, ACR50, } \\
\text { and ACR70 } \\
\text { improvement } \\
\text { from baseline } \\
\text { measured at all } \\
\text { visits to } \\
\text { month } 6\end{array}$ & [72] \\
\hline
\end{tabular}


(Table 2) contd...

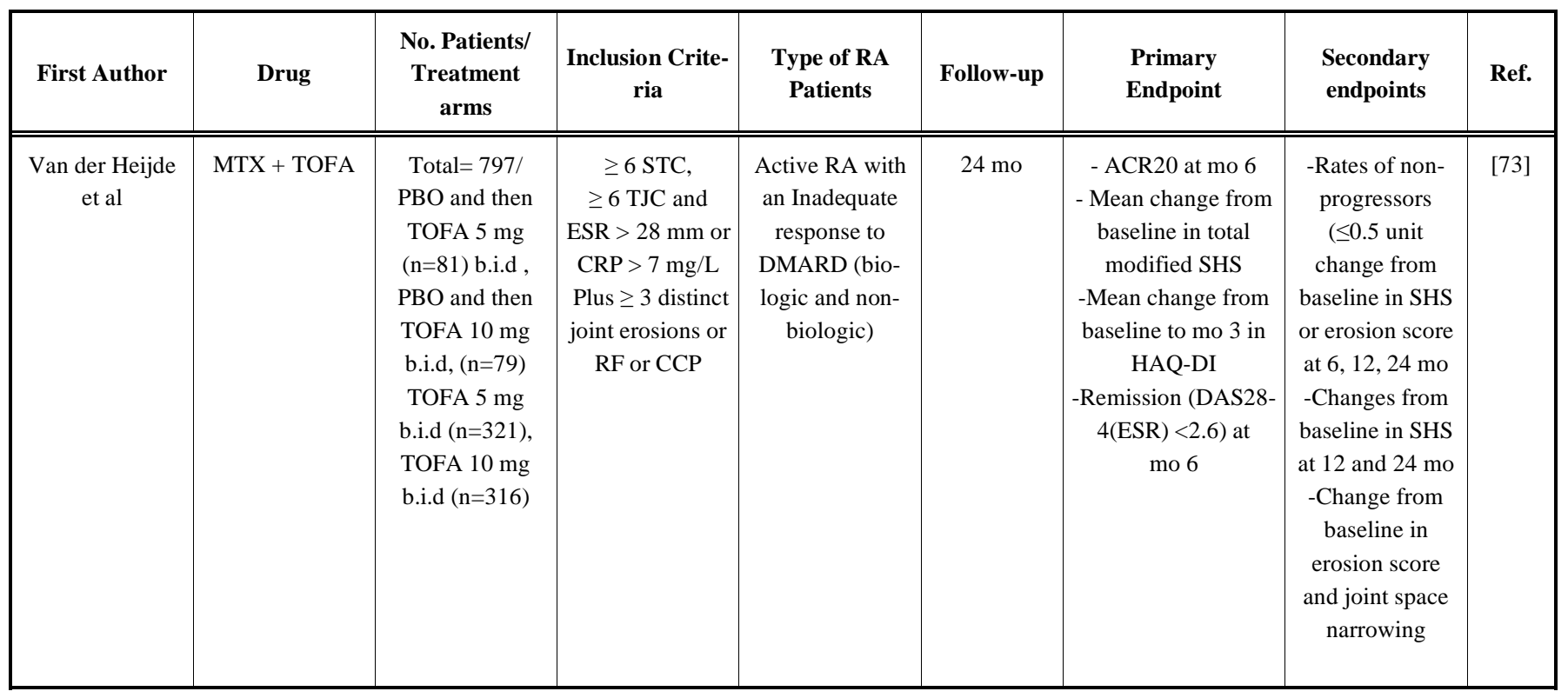

ADA: Adalimumab, b.id: twice daily, anti-CCP: antibodies to cyclic citrullinated peptide , CRP: C Reactive protein, DAS28-4 (ESR): Disease Activity Score-28 joints, 4 variables including ESR, DAS28-3(CRP):Disease Activity Score-28 joints , 3 variables including CRP, ESR: erythrocyte sedimentation rate, ETC: Etanercept, HAQ-DI: Health Assessment questionnaire-disability index, INF: Infliximab, Mo: Months, MTX: Methotrexate, PBO: Placebo, RF: Rheumatoid factor,

SHS: Sharp/van der Heijde score, SJC: Swelling joint count, TJC: Tender joint count, TNF: Tumor necrosis factor, TOFA: Tofacitinib

Table 3. Long-Term Safety of Fostamatinib from up to 2 Years Exposure [74]

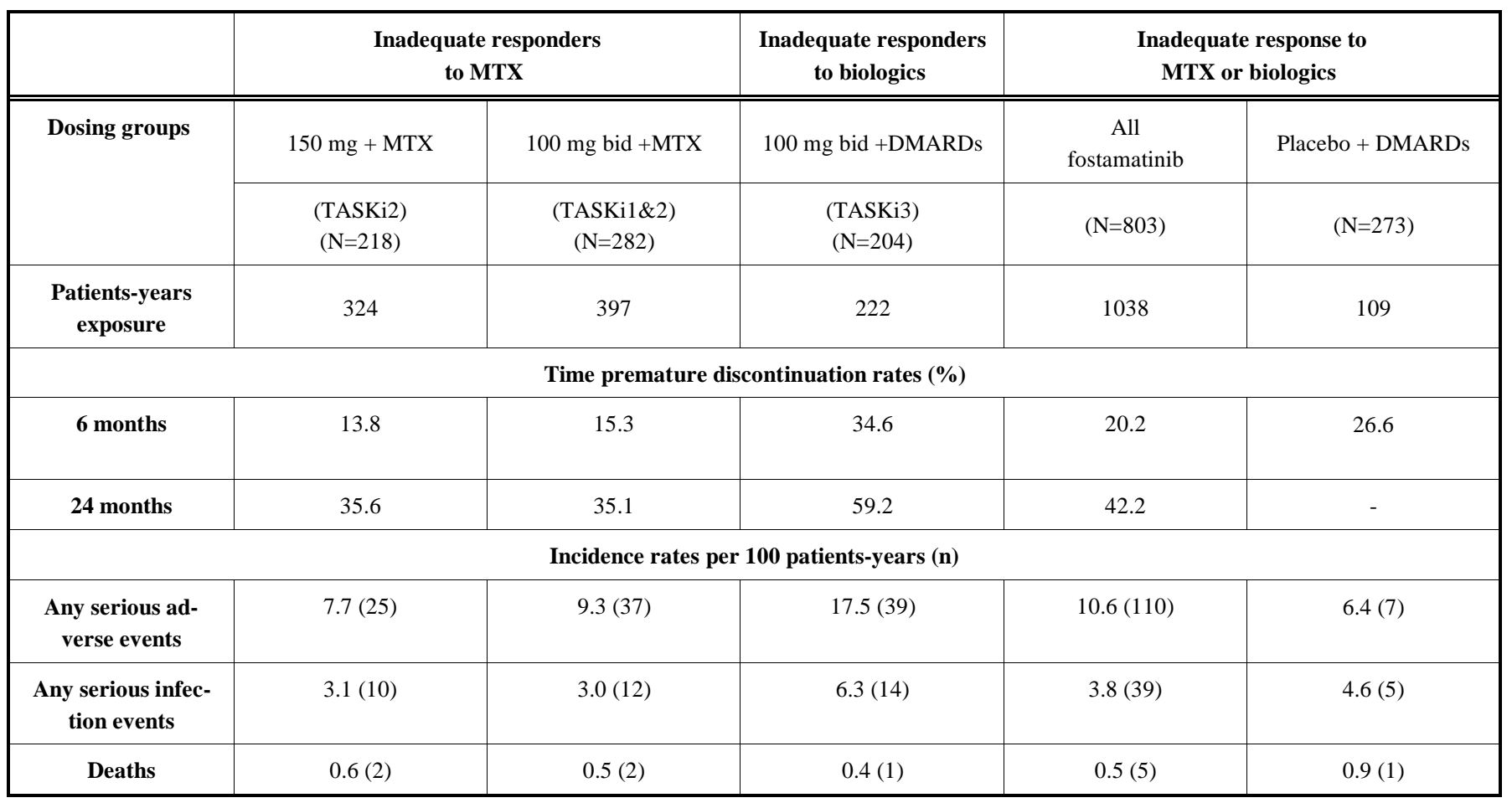

The primary endpoint (ACR20 response at month 6) was met in $51.5 \%$ and $52.6 \%$ of patients in $5 \mathrm{mg}$ and $10 \mathrm{mg}$ of tofacitinib, respectively, in $47.2 \%$ of adalimumab vs $28.3 \%$ in placebo group ( $p<0.001$ for all comparisons). Additionally, ACR50 and ACR70 responses, change from baseline in DAS-28-4 (ESR) and HAQ-DI scores were significant higher in active treatment groups vs placebo. Physical func- tion was improved, and rates of remission based upon the DAS28-4(ESR) were significantly higher after 6 months with the active treatments $(6 \%, 13 \%$, and $7 \%$ versus $1 \%$, respectively). Tofacitinib have similar responses rates to adalimumab, however this study was not designed or powered to directly compare the efficacy of tofacitinib with adalimumab. A rapid responses (ACR20 and ACR50) in 
active treatment group vs placebo were noted after only one month of treatment ( $\mathrm{p}<0.001$ for all comparisons).

Additional Phase III studies include a study in TNF failures and a structural inhibition study. In addition there a large long term extension study in progress.

Burmester et al [72] evaluated the efficacy of tofacitinib in patients with an active RA with an inadequate response or intolerance to one or more TNF. Before study medication assignment, a biologic wash-out period was done including 4 weeks for etanercept; 6 weeks for adalimumab; 8 weeks for infliximab; 10 weeks for golimumab and 3 months for certolizumab pegol.

Patients were randomly assigned in a 2:2:1:1 ratio to tofacitinib $5 \mathrm{mg}$ b.i.d; tofacitinib $10 \mathrm{mg}$ b.i.d; placebo for 3 months then advanced to $5 \mathrm{mg}$ tofacitinib b.i.d; or placebo for 3 months then advanced to $10 \mathrm{mg}$ tofacitinib b.i.d. At 3 months, ACR20 response rates were $42 \%$ for tofacitinib 5 $\mathrm{mg}$ and $48 \%$ for $10 \mathrm{mg}$ versus $24 \%$ for placebo. At 6 months, these rates were $52 \%$ for tofacitinib $5 \mathrm{mg}$ and $55 \%$ for tofacitinib $10 \mathrm{mg}$. Although remission $(\mathrm{DAS} 28<2.6)$ was achieved in a small proportion of patients, those patients who received tofacitinib treatment had better remission rates than placebo group $(6.7 \%$ and $8.8 \%$ for tofacitinib 5 and $10 \mathrm{mg}$ b.i.d, respectively). Worth mentioning, a post-hoc analysis of ACR20 response rate in patients treated with one, two or three or more TNF showed that the efficacy of tofacitinib was observed in patients irrespective of the number of prior TNF used

Finally, van der Heijde et al [73], evaluated the efficacy of tofacitinib over structural damage after 24 months of follow up in patients with active RA with an inadequate response to MTX with evidence of 3 or more distinct erosions on hand or foot or, in absence of joint erosions, the presence of rheumatoid factor or anti-cyclic citrullinated antibodies. Similar than the previous study [72], patients were assigned to four different treatments and then switched from placebo to tofacitinib (either 5 or $10 \mathrm{mg}$ ) for those cases without $\geq$ $20 \%$ clinical improvement after 3 months of follow-up.

ACR20 responses at month 6 were 51, 62\% and 25 for patients receiving tofacitinib $5 \mathrm{mg}, 10 \mathrm{mg}$ or placebo, respectively. At the same time, patients receiving tofacitinib had less structural damage [measured my changes in total modified Sharp/van der Heijde score, SHS)] than patients receiving placebo. Treatment with both tofacitinib doses lead to lesser progression from baseline in both components of SHS, including erosion score and joint space narrowing. Remission rates and ACR50 and ACR70 responses were also significantly higher in tofacitinib users. A post-hoc analysis showed that those patients treated with tofacitinib with poor prognosis factors had more marked effects over joint damage progression. In conclusion, this phase III study confirmed the clinical efficacy of tofacitinib in RA patients with previous failure to MTX treatment but also demonstrated for the first time the benefit over prevention of structural damage.

\section{Safety Profile}

\section{-Fostamatinib}

In all three phase II trials, fostamatinib therapy was generally well tolerated. The most common adverse events in
TASKi2 [66] were diarrhea in $11.8 \%$ and $19.1 \%$ of patients treated with tofacitinib $150 \mathrm{mg}$ o.d and $100 \mathrm{mg}$ b.i.d, respectively vs $3 \%$ of placebo and nausea in $5.9 \%$ and $4.6 \%$ of patients treated with tofacitinib $150 \mathrm{mg}$ o.d and $100 \mathrm{mg}$ b.i.d, respectively, vs $4.6 \%$ in placebo group. Other important side effects in active treatment group include liver aminotransferase elevations (ranging from 18-20\%), neutropenia ( $<1500$ cells) in around $7 \%$ of patients and elevation of blood pressure (BP) measures (mean elevation $5 \mathrm{~mm} \mathrm{Hg}$ ) in $29 \%$ of patients. In all cases, elevated BP responded to conventional anti-hypertensive treatment or fostamatinib dose reduction.

In TASKi3 [67] the most common adverse events in active treatment group were diarrhea $(12 \%)$ and headache $(10 \%)$. There were no opportunistic infections. Increase in liver aminotransferase was slightly higher in fostamatinib group (3\%) vs placebo $(0 \%)$. Neutropenia $(<1500$ cells) was uncommon, been reported in only $2 \%$ of fostamatinib group. No infections were reported with neutropenia. As occurred in TASKi2 trial, a elevation of BP was noticed in active treatment group, with a mean increase of systolic BP around $5 \mathrm{~mm} \mathrm{Hg}$. Again, all cases responded to antihypertensive treatment.

The accumulated long-term safety and tolerability data for fostamatinib was presented as an abstract at the ACR meeting in 2011 [74]. The results were taken from extension period of pivotal trials (TASKi 1,2 and 3) and from an ongoing open-label study (C-935788-012). Main results of the accumulated data are collected in Table 3. No new significant safety issues were identified. Overall, patients who had received prior biologics as compared to biologic naïve patients had a higher incidence rate of adverse events, including serious infections [74].

\section{-Tofacitinib:}

In the tofacitinib trials, the most common adverse events included headache, diarrhea, upper respiratory and urinary infections and herpes zoster among others [70,71]. Laboratory evaluations also revealed elevation of liver aminotransferases, dose-related increases in total cholesterol, HDL cholesterol, LDL cholesterol anemia, leucopenia and a small increase in serum creatinine levels. Serious infections were more common in tofacitinib group as compared with placebo. Those infections included cellulitis, respiratory infections, urinary tract infections rarely opportunistic infections such as tuberculosis. Main side effects in phase III trials are collected in Table 4 . Currently the safety profile shows similar infection rates as observed with known biologicals. The crude rate of serious infection events was 3/100 patientyears. The long term safety profile will be essential in determine the place of the kinase inhibitors in RA-rates of infection and rates of malignancy will be the important areas to follow.

\section{New TK Inhibitors}

\section{-INCB028050/LY3009104 (Baricitinib)}

Baricitinib is an orally administered JAK inhibitor. Currently, baricitinib is in Phase II development as a treatment for RA and psoriasis. There is an ongoing phase II trial evaluating the Safety and tolerability of INCB028050/ 
Table 4. Safety of Tofacitinib During phase III Trials

\begin{tabular}{|c|c|c|c|c|c|c|c|}
\hline & $\begin{array}{c}\text { Placebo } \\
\mathrm{N}=122\end{array}$ & $\begin{array}{c}\text { Tofacitinib } \\
\quad 5 \mathrm{mg} \\
\mathrm{N}=\mathbf{2 4 3}\end{array}$ & $\begin{array}{c}\text { Tofacitinib } \\
10 \mathrm{mg} \\
\mathrm{N}=\mathbf{2 4 5}\end{array}$ & $\begin{array}{c}\text { Placebo } \\
\mathrm{N}=108\end{array}$ & $\begin{array}{c}\text { Tofacitinib } \\
\quad 5 \mathrm{mg} \\
\text { N=204 }\end{array}$ & $\begin{array}{c}\text { Tofacitinib } \\
10 \mathrm{mg} \\
\mathrm{N}=201\end{array}$ & $\begin{array}{c}\text { Adalimu- } \\
\text { mab } \\
\mathrm{N}=204\end{array}$ \\
\hline Serious AE \% & 55 & 51 & 57 & 47 & 52 & 46 & 51 \\
\hline Discontinuation due to AE \% & 4 & 0.8 & 2 & 3 & 7 & 5 & 5 \\
\hline $\begin{array}{c}\text { Moderate to severe neutro- } \\
\text { penia } \%\end{array}$ & 0 & 0 & $<1.0$ & 0 & 1.1 & 1.6 & 0 \\
\hline $\begin{array}{c}\text { Decrease of } \mathrm{Hb} \\
(-1.0-3.0 \mathrm{mg} / \mathrm{dl}) \%\end{array}$ & 14 & 6 & 14 & 9 & 8 & 8 & 5 \\
\hline
\end{tabular}

AE: Adverse event, ALT: alanine aminotransferase, AST: aspartate aminotransferase, Hb: Hemoglobin, ULN: upper limit of the normal range

Table 5. ACR Responses at 6 Months in Trials of Biological Therapies and a TK Inhibitors in Patients with RA Who Had Inadequate Responses to DMARDs

\begin{tabular}{|c|c|c|c|c|c|c|c|}
\hline $\begin{array}{l}\text { Biologic } \\
\text { Treatment }\end{array}$ & Trial & $\begin{array}{c}\text { First author/ } \\
\text { Year }\end{array}$ & No. patients & ACR20 & ACR50 & ACR70 & Ref. \\
\hline $\begin{array}{c}\text { Abatacept } \\
(10 \mathrm{mg} / \mathrm{kg} \text { per month })\end{array}$ & NA & Kremer 2003 & 339 & $60 \%$ & $36 \%$ & $16 \%$ & [77] \\
\hline $\begin{array}{l}\text { Adalimumab ( } 40 \mathrm{mg} \\
\text { every } 2 \text { weeks) }\end{array}$ & $A R M A D A$ & Weinblatt 2003 & 271 & $67 \%$ & $55 \%$ & $27 \%$ & [78] \\
\hline $\begin{array}{c}\text { Etanercept } \\
(25 \mathrm{mg} \text { twice a week) }\end{array}$ & NA & Moreland 1999 & 234 & $59 \%$ & $40 \%$ & $14 \%$ & [80] \\
\hline $\begin{array}{c}\text { Golimumab } \\
\text { (50 mg per month) }\end{array}$ & GO-FORWARD & Keystone 2009 & 444 & $60 \%$ & $38 \%$ & $18 \%$ & [81] \\
\hline $\begin{array}{c}\text { Rituximab } \\
\text { (2 pulses of } 1000 \mathrm{mg})\end{array}$ & DANCER & Emery 2006 & 465 & $54 \%$ & $34 \%$ & $20 \%$ & [83] \\
\hline $\begin{array}{c}\text { Tocilizumab } \\
\text { (8 } \mathrm{mg} / \mathrm{kg} \text { every month) }\end{array}$ & OPTION & Smolen 2008 & 622 & $59 \%$ & $44 \%$ & $22 \%$ & [84] \\
\hline $\begin{array}{l}\text { Fostamatinib (100 mg } \\
\text { twice daily) }\end{array}$ & TASKi 2 & Weinblatt 2010 & 457 & $66 \%$ & $43 \%$ & $28 \%$ & [66] \\
\hline $\begin{array}{l}\text { Tofacitinib } * *(5 \mathrm{mg} \\
\text { and } 10 \mathrm{mg} \text { b.i.d })\end{array}$ & ORAL solo & $\begin{array}{l}\text { Fleischmann } \\
\quad 2012\end{array}$ & 611 & $\begin{array}{l}60 \% \\
66 \%\end{array}$ & $\begin{array}{l}31 \% \\
37 \%\end{array}$ & $\begin{array}{l}15 \% \\
20 \%\end{array}$ & [70] \\
\hline
\end{tabular}

*Biologic agents are presented in alphabetical order. ${ }^{*}$ ATTRACT study: Clinical assessment at 30 weeks

** ACR reponse at month $3, \mathrm{NA}$ : Not available

LY3009104 (baricitinib) in patients with active RA who have had inadequate response to any DMARD therapy including biologics. Eligible patients receive one of three doses (4, 7 or $10 \mathrm{mg}$ q.d) of baricitinib or placebo. The primary outcomes include the safety and tolerability and ACR20 response after 3 months of treatment. Additionally, 
other secondary outcomes will be evaluated ACR 20, 50, 70 and 90 responses after 6 months of follow-up.
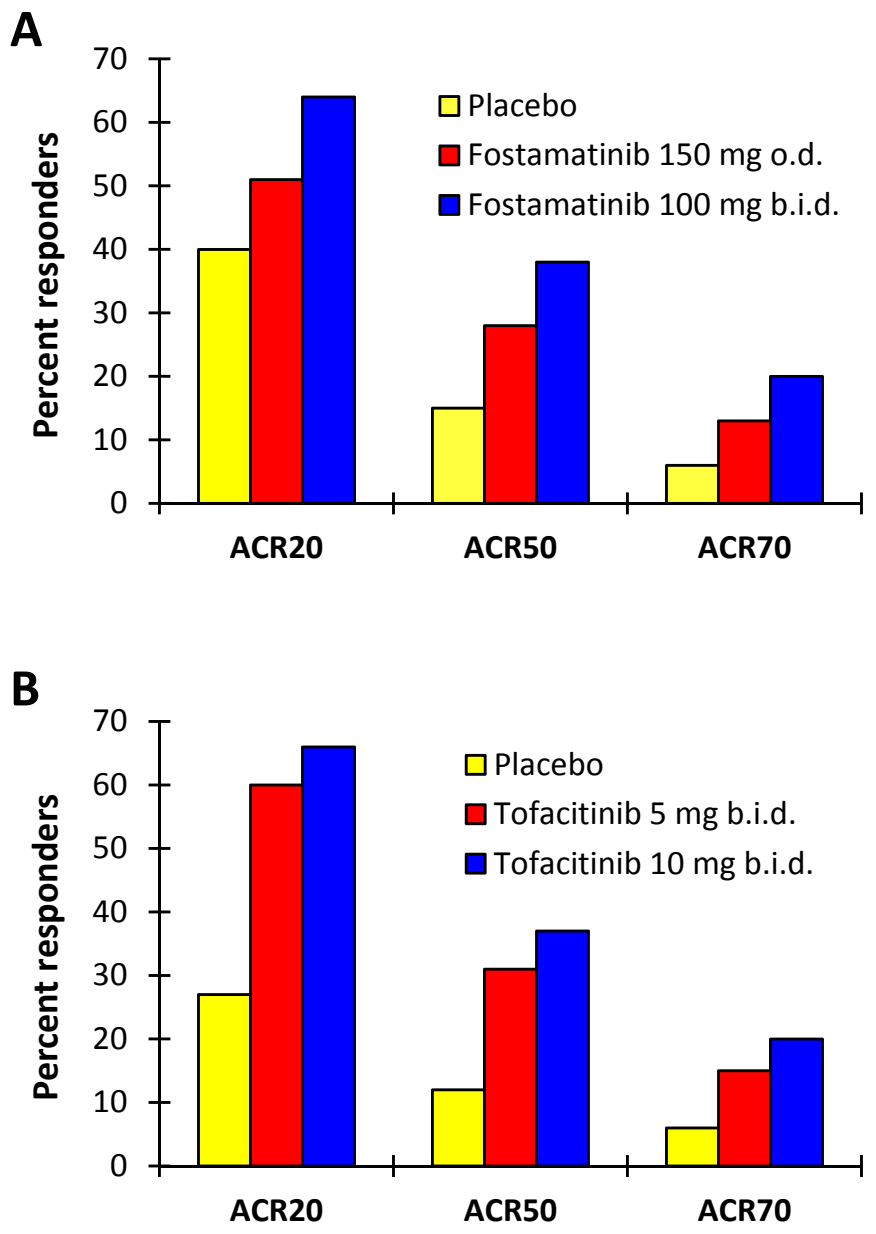

Fig. (3). ACR20, ACR50 and ACR70 responses after 12 weeks of follow-up in active RA patients with an inadequate response to MTX. Modified from [65,70].

Recently, at the EULAR meeting held in 2012 the results of the efficacy and safety of baricitinib vs placebo in 301 patients with moderate to severe RA with inadequate response to MTX were presented [75]. Eligible patients were assigned to four different doses of LY3009104 (1, 2, 4, or 8 $\mathrm{mg}$ ) for 12 weeks. The primary endpoint evaluated the efficacy of baricitinib was assessed by the combined proportion of patients in the 4-mg and 8-mg dose groups who achieved an ACR20 response compared to placebo after 12 weeks of treatment.

A total of $76 \%$ of the combined group 4- and 8-mg (75\% of the 4-mg and $78 \%$ of the $8-\mathrm{mg}$ dose) achieved ACR20 responses compared with $41 \%$ of placebo ( $\mathrm{p} \leq .001$ ). Additionally, a greater proportion of patients treated with 4-mg (37\%) and 8-mg (22\%) achieved disease remission (DAS28CRP < 2.6). Most adverse events were mild. A similar rate of infections was observed in combined group (14\%) and placebo (12\%). No deaths or opportunistic infections occurred in the active treatment.
Several other JAK inhibitors are also in clinical trials so there is great interest in this pathway.

\section{CONCLUSIONS AND FUTURE DIRECTIONS}

Certainly, TK inhibitors open a new avenue of therapy for RA bringing, if possible, more alternatives for the management of RA. The short-term results demonstrate that TK inhibitors are at least similar in terms of control of disease symptoms to biologic therapies (See Table 5). Fostamatinib and tofacitinib pivotal trials demonstrated ACR 20, 50 and 70 responses around 60, 40 and 20\% respectively (Fig. 3). Additionally, they have been shown to improve physical function of patients, from the earliest stages of treatment.

Nonetheless, there is still limited information about the long-term tolerability and efficacy over time.

\section{CONFLICT OF INTEREST}

The author(s) confirm that this article content has no conflicts of interest.

\section{ACKNOWLEDGEMENTS}

The authors are enormously grateful to Michael E Weinblatt by his contributions and critical review of the content of this article.

\begin{tabular}{|c|c|c|}
\hline \multicolumn{3}{|c|}{ ABBREVIATIONS } \\
\hline ACR & $=$ & American College of Rheumatology \\
\hline CRP & $=$ & C-reactive protein \\
\hline DAS & $=$ & Disease activity score \\
\hline DMARD & $=$ & disease-modifying antirheumatic drugs \\
\hline ESR & $=$ & Erythrocyte sedimentation rate \\
\hline FACIT & $=$ & $\begin{array}{l}\text { Functional Assessment of Chronic Illness } \\
\text { Therapy }\end{array}$ \\
\hline HAQ-DI & $=$ & $\begin{array}{l}\text { Health assessment questionnaire-- } \\
\text { Disability index }\end{array}$ \\
\hline IFN & $=$ & Interferon \\
\hline IL & $=$ & Interleukin \\
\hline JAK & $=$ & Janus kinase \\
\hline MTX & $=$ & Methotrexate \\
\hline RA & $=$ & Rheumatoid arthritis \\
\hline SLE & $=$ & Systemic lupus erythematosus \\
\hline Syk & $=$ & Spleen tyrosine kinase \\
\hline SHS & $=$ & Sharp/van der Heijde score \\
\hline TK & $=$ & tyrosine kinase \\
\hline Tyk2 & $=$ & Tyrosine kinase 2 \\
\hline $\mathrm{TNF}$ & $=$ & tumor necrosis factor \\
\hline
\end{tabular}

\section{REFERENCES}

[1] McInnes, I. B.; O'Dell, J. R. State-of-the-art: rheumatoid arthritis. Ann. Rheum. Dis., 2010, 11(69), 1898-1906. 
[2] Gomez-Puerta, J. A.; Bosch, X. Therapy: Spleen tyrosine kinase inhibitors--novel therapies for RA? Nat. Rev. Rheumato.l, 2011, 3(7), 134-136.

[3] Robinson, D. R.; Wu, Y. M.; Lin, S. F. The protein tyrosine kinase family of the human genome. Oncogene, 2000, 49(19), 5548-5557.

[4] Lemmon, M. A.; Schlessinger, J. Cell signaling by receptor tyrosine kinases. Cell, 2010, 7(141), 1117-1134.

[5] Deininger, M.; Buchdunger, E.; Druker, B. J. The development of imatinib as a therapeutic agent for chronic myeloid leukemia. Blood, 2005, 7(105), 2640-2653.

[6] Druker, B. J. Translation of the Philadelphia chromosome into therapy for CML. Blood, 2008, 13(112), 4808-4817.

[7] Zhang, J.; Yang, P. L.; Gray, N. S. Targeting cancer with small molecule kinase inhibitors. Nat. Rev. Cancer, 2009, 1(9), 28-39.

[8] Mócsai, A.; Ruland, J.; Tybulewicz, V. L. The SYK tyrosine kinase: a crucial player in diverse biological functions. Nat. Rev. Immunol., 2010, 6(10), 387-402.

[9] O'Shea, J. J.; Plenge, R. JAK and STAT signaling molecules in immunoregulation and immune-mediated disease. Immunity, 2012, 4(36), 542-550.

[10] Lowell, C. A. Src-family kinases: rheostats of immune cell signaling. Mol. Immunol., 2004, 6-7(41), 631-643.

[11] Zarbock, A.; Ley, K. Protein tyrosine kinases in neutrophil activation and recruitment. Arch. Biochem. Biophys., 2011, 2(510), 112119.

[12] Kurosaki, T.; Hikida, M. Tyrosine kinases and their substrates in B lymphocytes. Immunol. Rev., 2009, 1(228), 132-148.

[13] Au-Yeung, B. B.; Deindl, S.; Hsu, L. Y.; Palacios, E. H.; Levin, S. E.; Kuriyan, J.; Weiss, A. The structure, regulation, and function of ZAP-70. Immunol. Rev., 2009, 1(228), 41-57.

[14] Takayanagi, H. Osteoimmunology: shared mechanisms and crosstalk between the immune and bone systems. Nat. Rev. Immunol., 2007, 4(7), 292-304.

[15] Kasirer-Friede, A.; Kahn, M. L.; Shattil, S. J. Platelet integrins and immunoreceptors. Immunol. Rev., 2007, 218, 247-264.

[16] Suzuki-Inoue, K.; Inoue, O.; Ozaki, Y. Novel platelet activation receptor CLEC-2: from discovery to prospects. J. Thromb. Haemost., 2011, 9(Suppl 1), 44-55.

[17] Batchu, S. N.; Korshunov, V. A. Novel tyrosine kinase signaling pathways: implications in vascular remodeling. Curr. Opin. Nephrol. Hypertens., 2012, 2(21), 122-127.

[18] Zhao, X.; Guan, J. L. Focal adhesion kinase and its signaling pathways in cell migration and angiogenesis. Adv. Drug Deliv Rev, 2011, 8(63), 610-5.

[19] Mocsai, A.; Ruland, J.; Tybulewicz, V. L. The SYK tyrosine kinase: a crucial player in diverse biological functions. Nat. Rev. Immunol., 2010, 6(10), 387-402.

[20] Costello, P. S.; Turner, M.; Walters, A. E.; Cunningham, C. N.; Bauer, P. H.; Downward, J.; Tybulewicz, V. L. Critical role for the tyrosine kinase Syk in signalling through the high affinity IgE receptor of mast cells. Oncogene, 1996, 12(13), 2595-2605.

[21] Crowley, M. T.; Costello, P. S.; Fitzer-Attas, C. J.; Turner, M.; Meng, F.; Lowell, C.; Tybulewicz, V. L.; DeFranco, A. L. A critical role for Syk in signal transduction and phagocytosis mediated by $\mathrm{Fc} \gamma$ receptors on macrophages. J. Exp. Med., 1997, 7(186), 1027-1039.

[22] Kiefer, F.; Brumell, J.; Al-Alawi, N.; Latour, S.; Cheng, A.; Veillette, A.; Grinstein, S.; Pawson, T. The Syk protein tyrosine kinase is essential for $\mathrm{Fc} \gamma$ receptor signaling in macrophages and neutrophils. Mol. Cell. Biol., 1998, 7(18), 4209-4220.

[23] Monroe, J. G. ITAM-mediated tonic signalling through pre-BCR and BCR complexes. Nat. Rev. Immunol., 2006, 4(6), 283-294.

[24] MA3csai, A.; Zhou, M.; Meng, F.; Tybulewicz, V. L.; Lowell, C. A. Syk is required for integrin signaling in neutrophils. Immunity, 2002, 4(16), 547-558.

[25] Zarbock, A.; Lowell, C. A.; Ley, K. Spleen tyrosine kinase Syk is necessary for E-selectin-induced $\alpha_{L} \beta_{2}$ integrin-mediated rolling on intercellular adhesion molecule-1. Immunity, 2007, 6(26), 773-783.

[26] Sancho, D.; Reis e Sousa, C. Signaling by myeloid C-type lectin receptors in immunity and homeostasis. Annu. Rev. Immunol., 2012 30), 491-529.

[27] Mócsai, A.; Humphrey, M. B.; Van Ziffle, J. A.; Hu, Y.; Burghardt, A.; Spusta, S. C.; Majumdar, S.; Lanier, L. L.; Lowell, C. A.; Nakamura, M. C. The immunomodulatory adapter proteins DAP12 and $\mathrm{Fc}$ receptor $\gamma$-chain $(\mathrm{FcR} \gamma)$ regulate development of functional osteoclasts through the Syk tyrosine kinase. Proc. Natl. Acad. Sci. USA, 2004, 16(101), 6158-6163.

[28] Cha, H. S.; Boyle, D. L.; Inoue, T.; Schoot, R.; Tak, P. P.; Pine, P.; Firestein, G. S. A novel spleen tyrosine kinase inhibitor blocks cJun N-terminal kinase-mediated gene expression in synoviocytes. J. Pharmacol. Exp. Ther., 2006, 2(317), 571-578.

[29] Mun, S. H.; Kim, J. W.; Nah, S. S.; Ko, N. Y.; Lee, J. H.; Kim, J. D.; Kim do, K.; Kim, H. S.; Choi, J. D.; Kim, S. H.; Lee, C. K.; Park, S. H.; Kim, B. K.; Kim, Y. M.; Choi, W. S. Tumor necrosis factor $\alpha$-induced interleukin-32 is positively regulated via the Syk/protein kinase $\mathrm{C} \delta / \mathrm{JNK}$ pathway in rheumatoid synovial fibroblasts. Arthritis Rheum., 2009, 3(60), 678-685.

[30] Yanagi, S.; Inatome, R.; Ding, J.; Kitaguchi, H.; Tybulewicz, V. L.; Yamamura, H. Syk expression in endothelial cells and their morphologic defects in embryonic Syk-deficient mice. Blood, 2001, 9(98), 2869-2871.

[31] Kazerounian, S.; Duquette, M.; Reyes, M. A.; Lawler, J. T.; Song, K.; Perruzzi, C.; Primo, L.; Khosravi-Far, R.; Bussolino, F.; Rabinovitz, I.; Lawler, J. Priming of the vascular endothelial growth factor signaling pathway by thrombospondin-1, CD36, and spleen tyrosine kinase. Blood, 2011, 17(117), 4658-4566.

[32] Braselmann, S.; Taylor, V.; Zhao, H.; Wang, S.; Sylvain, C.; Baluom, M.; Qu, K.; Herlaar, E.; Lau, A.; Young, C.; Wong, B. R.; Lovell, S.; Sun, T.; Park, G.; Argade, A.; Jurcevic, S.; Pine, P.; Singh, R.; Grossbard, E. B.; Payan, D. G.; Masuda, E. S. R406, an orally available spleen tyrosine kinase inhibitor blocks Fc receptor signaling and reduces immune complex-mediated inflammation. $J$. Pharmacol. Exp. Ther., 2006, 3(319), 998-1008.

[33] Pine, P. R.; Chang, B.; Schoettler, N.; Banquerigo, M. L.; Wang, S.; Lau, A.; Zhao, F.; Grossbard, E. B.; Payan, D. G.; Brahn, E. Inflammation and bone erosion are suppressed in models of rheumatoid arthritis following treatment with a novel Syk inhibitor. Clin. Immunol., 2007, 3(124), 244-257.

[34] Pine, P. R.; Bahjat, R.; Chang, B.; Taylor, V.; Markovstov, V.; Hitoshi, Y.; Grossbard, E. An orally bioavailable Inhibitor of FLT3 and Syk kinases prevents tumor growth in subcutaneously implanted human tumor xenografts and promotes cell death of FLT3 mutant AML cells. Blood, 2005, 11(106), 74A.

[35] Clemens, G. R.; Schroeder, R. E.; Magness, S. H.; Weaver, E. V.; Lech, J. W.; Taylor, V. C.; Masuda, E. S.; Baluom, M.; Grossbard, E. B. Developmental toxicity associated with receptor tyrosine kinase Ret inhibition in reproductive toxicity testing. Birth. Defects Res. A. Clin. Mol. Teratol., 2009, 2(85), 130-136.

[36] Jakus, Z.; Simon, E.; Balázs, B.; Mócsai, A. Genetic deficiency of Syk protects mice from autoantibody-induced arthritis. Arthritis Rheum., 2010, 7(62), 1899-1910.

[37] Bahjat, F. R.; Pine, P. R.; Reitsma, A.; Cassafer, G.; Baluom, M.; Grillo, S.; Chang, B.; Zhao, F. F.; Payan, D. G.; Grossbard, E. B.; Daikh, D. I. An orally bioavailable spleen tyrosine kinase inhibitor delays disease progression and prolongs survival in murine lupus. Arthritis Rheum., 2008, 5(58), 1433-1444.

[38] Deng, G. M.; Liu, L.; Bahjat, F. R.; Pine, P. R.; Tsokos, G. C. Suppression of skin and kidney disease by inhibition of spleen tyrosine kinase in lupus-prone mice. Arthritis Rheum., 2012, 7(62), 2086-2092.

[39] Ghoreschi, K.; Laurence, A.; O'Shea, J. J. Janus kinases in immune cell signaling. Immunol. Rev., 2009, 1(228), 273-287.

[40] Gadina, M.; Hilton, D.; Johnston, J. A.; Morinobu, A.; Lighvani, A.; Zhou, Y. J.; Visconti, R.; O'Shea, J. J. Signaling by type I and II cytokine receptors: ten years after. Curr. Opin. Immunol., 2001, 3(13), 363-373.

[41] Renauld, J. C. Class II cytokine receptors and their ligands: key antiviral and inflammatory modulators. Nat. Rev. Immunol., 2003, 8(3), 667-676.

[42] Haan, C.; Kreis, S.; Margue, C.; Behrmann, I. Jaks and cytokine receptors--an intimate relationship. Biochem. Pharmacol., 2006, 11(72), 1538-1546.

[43] Rodig, S. J.; Meraz, M. A.; White, J. M.; Lampe, P. A.; Riley, J. K.; Arthur, C. D.; King, K. L.; Sheehan, K. C.; Yin, L.; Pennica, D.; Johnson, E. M., Jr.; Schreiber, R. D. Disruption of the Jak1 gene demonstrates obligatory and nonredundant roles of the Jaks in cytokine-induced biologic responses. Cell, 1998, 3(93), 373-383.

[44] Neubauer, H.; Cumano, A.; Muller, M.; Wu, H.; Huffstadt, U.; Pfeffer, K. Jak2 deficiency defines an essential developmental checkpoint in definitive hematopoiesis. Cell, 1998, 3(93), 397-409. 
[45] Macchi, P.; Villa, A.; Giliani, S.; Sacco, M. G.; Frattini, A.; Porta, F.; Ugazio, A. G.; Johnston, J. A.; Candotti, F.; O'Shea, J. J.; et al. Mutations of Jak-3 gene in patients with autosomal severe combined immune deficiency (SCID). Nature, 1995, 6544(377), 65-68.

[46] Russell, S. M.; Tayebi, N.; Nakajima, H.; Riedy, M. C.; Roberts, J. L.; Aman, M. J.; Migone, T. S.; Noguchi, M.; Markert, M. L.; Buckley, R. H.; O'Shea, J. J.; Leonard, W. J. Mutation of Jak3 in a patient with SCID: essential role of Jak3 in lymphoid development. Science, 1995, 5237(270), 797-800.

[47] Nosaka, T.; van Deursen, J. M.; Tripp, R. A.; Thierfelder, W. E.; Witthuhn, B. A.; McMickle, A. P.; Doherty, P. C.; Grosveld, G. C.; Ihle, J. N. Defective lymphoid development in mice lacking Jak3. Science, 1995, 5237(270), 800-802.

[48] Park, S. Y.; Saijo, K.; Takahashi, T.; Osawa, M.; Arase, H.; Hirayama, N.; Miyake, K.; Nakauchi, H.; Shirasawa, T.; Saito, T. Developmental defects of lymphoid cells in Jak3 kinase-deficient mice. Immunity, 1995, 6(3), 771-782.

[49] Karaghiosoff, M.; Neubauer, H.; Lassnig, C.; Kovarik, P.; Schindler, H.; Pircher, H.; McCoy, B.; Bogdan, C.; Decker, T.; Brem, G.; Pfeffer, K.; Muller, M. Partial impairment of cytokine responses in Tyk2-deficient mice. Immunity, 2000, 4(13), 549-560.

[50] Shimoda, K.; Kato, K.; Aoki, K.; Matsuda, T.; Miyamoto, A.; Shibamori, M.; Yamashita, M.; Numata, A.; Takase, K.; Kobayashi, S.; Shibata, S.; Asano, Y.; Gondo, H.; Sekiguchi, K.; Nakayama, K.; Nakayama, T.; Okamura, T.; Okamura, S.; Niho, Y. Tyk2 plays a restricted role in IFN alpha signaling, although it is required for IL-12-mediated T cell function. Immunity, 2000, 4(13), $561-571$

[51] Minegishi, Y.; Saito, M.; Morio, T.; Watanabe, K.; Agematsu, K.; Tsuchiya, S.; Takada, H.; Hara, T.; Kawamura, N.; Ariga, T.; Kaneko, H.; Kondo, N.; Tsuge, I.; Yachie, A.; Sakiyama, Y.; Iwata, T.; Bessho, F.; Ohishi, T.; Joh, K.; Imai, K.; Kogawa, K.; Shinohara, M.; Fujieda, M.; Wakiguchi, H.; Pasic, S.; Abinun, M.; Ochs, H. D.; Renner, E. D.; Jansson, A.; Belohradsky, B. H.; Metin, A.; Shimizu, N.; Mizutani, S.; Miyawaki, T.; Nonoyama, S.; Karasuyama, $\mathrm{H}$. Human tyrosine kinase 2 deficiency reveals its requisite roles in multiple cytokine signals involved in innate and acquired immunity. Immunity, 2006, 5(25), 745-755.

[52] Kralovics, R.; Passamonti, F.; Buser, A. S.; Teo, S. S.; Tiedt, R.; Passweg, J. R.; Tichelli, A.; Cazzola, M.; Skoda, R. C. A gain-offunction mutation of JAK2 in myeloproliferative disorders. $N$. Engl. J. Med., 2005, 17(352), 1779-1790.

[53] James, C.; Ugo, V.; Le Couedic, J. P.; Staerk, J.; Delhommeau, F.; Lacout, C.; Garcon, L.; Raslova, H.; Berger, R.; BennaceurGriscelli, A.; Villeval, J. L.; Constantinescu, S. N.; Casadevall, N.; Vainchenker, W. A unique clonal JAK2 mutation leading to constitutive signalling causes polycythaemia vera. Nature, 2005, 7037(434), 1144-1148.

[54] Levine, R. L.; Wadleigh, M.; Cools, J.; Ebert, B. L.; Wernig, G.; Huntly, B. J.; Boggon, T. J.; Wlodarska, I.; Clark, J. J.; Moore, S.; Adelsperger, J.; Koo, S.; Lee, J. C.; Gabriel, S.; Mercher, T.; D'Andrea, A.; Frohling, S.; Dohner, K.; Marynen, P.; Vandenberghe, P.; Mesa, R. A.; Tefferi, A.; Griffin, J. D.; Eck, M. J.; Sellers, W. R.; Meyerson, M.; Golub, T. R.; Lee, S. J.; Gilliland, D. G. Activating mutation in the tyrosine kinase JAK2 in polycythemia vera, essential thrombocythemia, and myeloid metaplasia with myelofibrosis. Cancer Cell., 2005, 4(7), 387-397.

[55] Baxter, E. J.; Scott, L. M.; Campbell, P. J.; East, C.; Fourouclas, N.; Swanton, S.; Vassiliou, G. S.; Bench, A. J.; Boyd, E. M.; Curtin, N.; Scott, M. A.; Erber, W. N.; Green, A. R. Acquired mutation of the tyrosine kinase JAK2 in human myeloproliferative disorders. Lancet, 2005, 9464(365), 1054-1061.

[56] Levine, R. L.; Pardanani, A.; Tefferi, A.; Gilliland, D. G. Role of JAK2 in the pathogenesis and therapy of myeloproliferative disorders. Nat. Rev. Cancer, 2007, 9(7), 673-683.

[57] McInnes, I. B.; Schett, G. Cytokines in the pathogenesis of rheumatoid arthritis. Nat. Rev. Immunol., 2007, 6(7), 429-442.

[58] Quintas-Cardama, A.; Kantarjian, H.; Cortes, J.; Verstovsek, S. Janus kinase inhibitors for the treatment of myeloproliferative neoplasias and beyond. Nat. Rev. Drug Discov., 2011, 2(10), 127-140.

[59] Flanagan, M. E.; Blumenkopf, T. A.; Brissette, W. H.; Brown, M. F.; Casavant, J. M.; Shang-Poa, C.; Doty, J. L.; Elliott, E. A.; Fisher, M. B.; Hines, M.; Kent, C.; Kudlacz, E. M.; Lillie, B. M.; Magnuson, K. S.; McCurdy, S. P.; Munchhof, M. J.; Perry, B. D.; Sawyer, P. S.; Strelevitz, T. J.; Subramanyam, C.; Sun, J.; Whipple, D. A.; Changelian, P. S. Discovery of CP-690,550: a potent and se- lective Janus kinase (JAK) inhibitor for the treatment of autoimmune diseases and organ transplant rejection. J. Med. Chem., 2010, 24(53), 8468-8484.

[60] Milici, A. J.; Kudlacz, E. M.; Audoly, L.; Zwillich, S.; Changelian, P. Cartilage preservation by inhibition of Janus kinase 3 in two rodent models of rheumatoid arthritis. Arthritis Res. Ther., 2008, l(10), R14.

[61] Meyer, D. M.; Jesson, M. I.; Li, X.; Elrick, M. M.; FunckesShippy, C. L.; Warner, J. D.; Gross, C. J.; Dowty, M. E.; Ramaiah, S. K.; Hirsch, J. L.; Saabye, M. J.; Barks, J. L.; Kishore, N.; Morris, D. L. Anti-inflammatory activity and neutrophil reductions mediated by the JAK1/JAK3 inhibitor, CP-690,550, in rat adjuvantinduced arthritis. J. Inflamm. (Lond), 2010, 7, 41.

[62] Tanaka, Y.; Maeshima, Y.; Yamaoka, K. In vitro and in vivo analysis of a JAK inhibitor in rheumatoid arthritis. Ann. Rheum. Dis. 2012, 71 (Suppl 2), i70-74.

[63] Changelian, P. S.; Flanagan, M. E.; Ball, D. J.; Kent, C. R.; Magnuson, K. S.; Martin, W. H.; Rizzuti, B. J.; Sawyer, P. S.; Perry, B. D.; Brissette, W. H.; McCurdy, S. P.; Kudlacz, E. M.; Conklyn, M. J.; Elliott, E. A.; Koslov, E. R.; Fisher, M. B.; Strelevitz, T. J.; Yoon, K.; Whipple, D. A.; Sun, J.; Munchhof, M. J.; Doty, J. L.; Casavant, J. M.; Blumenkopf, T. A.; Hines, M.; Brown, M. F.; Lillie, B. M.; Subramanyam, C.; Shang-Poa, C.; Milici, A. J.; Beckius, G. E.; Moyer, J. D.; Su, C.; Woodworth, T. G.; Gaweco, A. S.; Beals, C. R.; Littman, B. H.; Fisher, D. A.; Smith, J. F.; Zagouras, P.; Magna, H. A.; Saltarelli, M. J.; Johnson, K. S.; Nelms, L. F.; Des Etages, S. G.; Hayes, L. S.; Kawabata, T. T.; Finco-Kent, D.; Baker, D. L.; Larson, M.; Si, M. S.; Paniagua, R.; Higgins, J.; Holm, B.; Reitz, B.; Zhou, Y. J.; Morris, R. E.; O'Shea, J. J.; Borie, D. C. Prevention of organ allograft rejection by a specific Janus kinase 3 inhibitor. Science, 2003, 5646(302), 875-878.

[64] Kudlacz, E.; Perry, B.; Sawyer, P.; Conklyn, M.; McCurdy, S. Brissette, W.; Flanagan; Changelian, P. The novel JAK-3 inhibitor CP-690550 is a potent immunosuppressive agent in various murine models. Am. J. Transplant., 2004, 1(4), 51-57.

[65] Weinblatt, M. E.; Kavanaugh, A.; Burgos-Vargas, R.; Dikranian, A. H.; Medrano-Ramirez, G.; Morales-Torres, J. L.; Murphy, F. T.; Musser, T. K.; Straniero, N.; Vicente-Gonzales, A. V.; Grossbard, E. Treatment of rheumatoid arthritis with a Syk kinase inhibitor: a twelve-week, randomized, placebo-controlled trial. Arthritis Rheum., 2008, 11(58), 3309-3318.

[66] Weinblatt, M. E.; Kavanaugh, A.; Genovese, M. C.; Musser, T. K.; Grossbard, E. B.; Magilavy, D. B. An oral spleen tyrosine kinase (Syk) inhibitor for rheumatoid arthritis. N. Engl. J. Med., 2010, 14(363), 1303-1312.

[67] Genovese, M. C.; Kavanaugh, A.; Weinblatt, M. E.; Peterfy, C.; DiCarlo, J.; White, M. L.; O'Brien, M.; Grossbard, E. B.; Magilavy, D. B. An oral Syk kinase inhibitor in the treatment of rheumatoid arthritis: a three-month randomized, placebo-controlled, phase II study in patients with active rheumatoid arthritis that did not respond to biologic agents. Arthritis Rheum., 2011, 2(63), 337-345.

[68] FDA approves Xeljanz for rheumatoid arthritis. 2012. (Accessed Nov 6 at http://www.fda.gov/NewsEvents/Newsroom/.)

[69] Kremer, J. M.; Bloom, B. J.; Breedveld, F. C.; Coombs, J. H.; Fletcher, M. P.; Gruben, D.; Krishnaswami, S.; Burgos-Vargas, R.; Wilkinson, B.; Zerbini, C. A.; Zwillich, S. H. The safety and efficacy of a JAK inhibitor in patients with active rheumatoid arthritis: Results of a double-blind, placebo-controlled phase IIa trial of three dosage levels of CP-690,550 versus placebo. Arthritis Rheum., 2009, 7(60), 1895-1905.

[70] Fleischmann, R.; Kremer, J.; Cush, J.; Schulze-Koops, H.; Connell, C. A.; Bradley, J. D.; Gruben, D.; Wallenstein, G. V.; Zwillich, S. H.; Kanik, K. S. Placebo-controlled trial of tofacitinib monotherapy in rheumatoid arthritis. N. Engl. J. Med., 2012, 6(367), 495-507.

[71] van Vollenhoven, R. F.; Fleischmann, R.; Cohen, S.; Lee, E. B.; Garcia Meijide, J. A.; Wagner, S.; Forejtova, S.; Zwillich, S. H.; Gruben, D.; Koncz, T.; Wallenstein, G. V.; Krishnaswami, S.; Bradley, J. D.; Wilkinson, B. Tofacitinib or adalimumab versus placebo in rheumatoid arthritis. N. Engl. J. Med., 2012, 6(367), 508-519.

[72] Burmester, G. R.; Blanco, R.; Charles-Schoeman, C.; Wollenhaupt, J.; Zerbini, C.; Benda, B.; Gruben, D.; Wallenstein, G.; Krishnaswami, S.; Zwillich, S. H.; Koncz, T.; Soma, K.; Bradley, J.; Mebus, C. Tofacitinib (CP-690,550) in combination with methotrexate in patients with active rheumatoid arthritis with an inadequate re- 
sponse to tumour necrosis factor inhibitors: a randomised phase 3 trial. Lancet, 2013, 9865(381), 451-460.

[73] van der Heijde, D.; Tanaka, Y.; Fleischmann, R.; Keystone, E.; Kremer, J.; Zerbini, C.; Cardiel, M. H.; Cohen, S.; Nash, P.; Song, Y. W.; Tegzova, D.; Wyman, B. T.; Gruben, D.; Benda, B.; Wallenstein, G.; Krishnaswami, S.; Zwillich, S. H.; Bradley, J. D.; Connell, C. A. Tofacitinib (CP-690,550) in patients with rheumatoid arthritis receiving methotrexate: Twelve-month data from a twenty-four-month phase III randomized radiographic study. Arthritis Rheum., 2013, 3(65), 559-570.

[74] Kavanaugh, A., Weinblatt ME, Genovese MC, Musser TK, Grossbard EB, Magilavy DB. Longer-Term Safety of Fostamatinib (R788) in Patients with Rheumatoid ArthritisAnalysis of Clinical Trial Data From up to 2 Years of Exposure. Arthritis Rheum. 2011, Suppl 10(63), 2594 [abstract].

[75] Keystone, E., Taylor P, Genovese M, Schlichting D, Beattie S, Gaich C. 12-week results of a Phase $2 b$ dose-ranging study of LY3009104 (INCB028050), an oral JAK1/JAK2 inhibitor, in combination with traditional DMARDS in patients with rheumatoid arthritis. Ann. Rheum. Dis., 2012, Suppl 3(71), 152.

[76] Tanaka, Y.; Suzuki, M.; Nakamura, H.; Toyoizumi, S.; Zwillich, S. H. Phase II study of tofacitinib (CP-690,550) combined with methotrexate in patients with rheumatoid arthritis and an inadequate response to methotrexate. Arthritis Care Res. (Hoboken), 2011, 8(63), 1150-1158.

[77] Kremer, J. M.; Westhovens, R.; Leon, M.; Di Giorgio, E.; Alten, R.; Steinfeld, S.; Russell, A.; Dougados, M.; Emery, P.; Nuamah, I. F.; Williams, G. R.; Becker, J. C.; Hagerty, D. T.; Moreland, L. W. Treatment of rheumatoid arthritis by selective inhibition of T-cell activation with fusion protein CTLA4Ig. N. Engl. J. Med., 2003, 20 (349), 1907-1915.

[78] Weinblatt, M. E.; Keystone, E. C.; Furst, D. E.; Moreland, L. W.; Weisman, M. H.; Birbara, C. A.; Teoh, L. A.; Fischkoff, S. A.; Chartash, E. K. Adalimumab, a fully human anti-tumor necrosis factor alpha monoclonal antibody, for the treatment of rheumatoid arthritis in patients taking concomitant methotrexate: the ARMADA trial. Arthritis Rheum., 2003, 1(48), 35-45.

[79] Keystone, E.; Heijde, D.; Mason, D., Jr.; Landewe, R.; Vollenhoven, R. V.; Combe, B.; Emery, P.; Strand, V.; Mease, P.; Desai, C.;
Pavelka, K. Certolizumab pegol plus methotrexate is significantly more effective than placebo plus methotrexate in active rheumatoid arthritis: findings of a fifty-two-week, phase III, multicenter, randomized, double-blind, placebo-controlled, parallel-group study. Arthritis Rheum., 2008, 11(58), 3319-3329.

[80] Moreland, L. W.; Schiff, M. H.; Baumgartner, S. W.; Tindall, E. A.; Fleischmann, R. M.; Bulpitt, K. J.; Weaver, A. L.; Keystone, E. C.; Furst, D. E.; Mease, P. J.; Ruderman, E. M.; Horwitz, D. A.; Arkfeld, D. G.; Garrison, L.; Burge, D. J.; Blosch, C. M.; Lange, M. L.; McDonnell, N. D.; Weinblatt, M. E. Etanercept therapy in rheumatoid arthritis. A randomized, controlled trial. Ann. Intern. Med., 1999, 6(130), 478-486.

[81] Keystone, E. C.; Genovese, M. C.; Klareskog, L.; Hsia, E. C.; Hall, S. T.; Miranda, P. C.; Pazdur, J.; Bae, S. C.; Palmer, W.; Zrubek, J.; Wiekowski, M.; Visvanathan, S.; Wu, Z.; Rahman, M. U. Golimumab, a human antibody to tumour necrosis factor \{alpha\} given by monthly subcutaneous injections, in active rheumatoid arthritis despite methotrexate therapy: the GO-FORWARD Study. Ann. Rheum. Dis., 2009, 6(68), 789-796.

[82] Maini, R.; St Clair, E. W.; Breedveld, F.; Furst, D.; Kalden, J.; Weisman, M.; Smolen, J.; Emery, P.; Harriman, G.; Feldmann, M.; Lipsky, P. Infliximab (chimeric anti-tumour necrosis factor alpha monoclonal antibody) versus placebo in rheumatoid arthritis patients receiving concomitant methotrexate: a randomised phase III trial. ATTRACT Study Group. Lancet, 1999, 9194(354), 19321939.

[83] Emery, P.; Fleischmann, R.; Filipowicz-Sosnowska, A.; Schechtman, J.; Szczepanski, L.; Kavanaugh, A.; Racewicz, A. J.; van Vollenhoven, R. F.; Li, N. F.; Agarwal, S.; Hessey, E. W.; Shaw, T. M. The efficacy and safety of rituximab in patients with active rheumatoid arthritis despite methotrexate treatment: results of a phase IIB randomized, double-blind, placebo-controlled, dose-ranging trial. Arthritis Rheum., 2006, 5(54), 1390-1400.

[84] Smolen, J. S.; Beaulieu, A.; Rubbert-Roth, A.; Ramos-Remus, C.; Rovensky, J.; Alecock, E.; Woodworth, T.; Alten, R. Effect of interleukin-6 receptor inhibition with tocilizumab in patients with rheumatoid arthritis (OPTION study): a double-blind, placebocontrolled, randomised trial. Lancet, 2008, 9617(371), 987-997. 